\title{
The effect of business cycle expectations on the German apprenticeship market: Estimating the impact of Covid-19
}

Citation for published version (APA):

Muehlemann, S., Pfeifer, H., \& Wittek, B. (2020). The effect of business cycle expectations on the German apprenticeship market: Estimating the impact of Covid-19. ROA. ROA Research Memoranda No. 008 https://doi.org/10.26481/umaror.2020008

Document status and date:

Published: 09/07/2020

DOI:

10.26481/umaror.2020008

Document Version:

Publisher's PDF, also known as Version of record

\section{Please check the document version of this publication:}

- A submitted manuscript is the version of the article upon submission and before peer-review. There can be important differences between the submitted version and the official published version of record.

People interested in the research are advised to contact the author for the final version of the publication, or visit the DOI to the publisher's website.

- The final author version and the galley proof are versions of the publication after peer review.

- The final published version features the final layout of the paper including the volume, issue and page numbers.

Link to publication

\footnotetext{
General rights rights.

- You may freely distribute the URL identifying the publication in the public portal. please follow below link for the End User Agreement:

www.umlib.nl/taverne-license

Take down policy

If you believe that this document breaches copyright please contact us at:

repository@maastrichtuniversity.nl

providing details and we will investigate your claim.
}

Copyright and moral rights for the publications made accessible in the public portal are retained by the authors and/or other copyright owners and it is a condition of accessing publications that users recognise and abide by the legal requirements associated with these

- Users may download and print one copy of any publication from the public portal for the purpose of private study or research.

- You may not further distribute the material or use it for any profit-making activity or commercial gain

If the publication is distributed under the terms of Article $25 \mathrm{fa}$ of the Dutch Copyright Act, indicated by the "Taverne" license above, 


\section{Maastricht University ROA}

The effect of business cycle expectations on the German apprenticeship market: Estimating the impact of Covid-19

Samuel Muehlemann

Harald Pfeifer

Bernhard Wittek

\section{ROA Research Memorandum}

ROA-RM-2020/8

Researchcentrum voor Onderwijs en Arbeidsmarkt | ROA Research Centre for Education and the Labour Market / ROA 


\title{
The effect of business cycle expectations on the German apprenticeship market: Estimating the impact of Covid-19
}

\author{
Samuel Muehlemann \\ Harald Pfeifer \\ Bernhard Wittek
}

ROA-RM-2020/8

July 2020

Research Centre for Education and the Labour Market Maastricht University P.O. Box 616, 6200 MD Maastricht, The Netherlands

$\mathrm{T}+31433883647 \mathrm{~F}+31433884914$

secretary-roa-sbe@maastrichtuniversity.nl www.roa.nl 


\title{
Abstract \\ The effect of business cycle expectations on the German apprenticeship market: Estimating the impact of Covid-19*
}

A firm's expectation about the future business cycle is an important determinant of the decision to train apprentices. As German firms typically train apprentices to either fill future skilled worker positions, or as a substitute for other types of labor, the current coronavirus crisis will have a strong and negative impact on the German economy according to the current business cycle expectations of German firms. To the extent that the training decision of a firm depends on its perception of the business cycle, we expect a downward shift in the firm's demand for apprentices and consequently also a decrease in the equilibrium number of apprenticeship contracts. We analyze German data on the apprenticeship from 2007 to 2019 and apply first-differences regressions to account for unobserved heterogeneity across states and occupations, allowing us to identify the association between changes in two popular measures of business cycle expectations (the ifo Business Climate Index and the ifo Employment Barometer) and subsequent changes in the demand for apprentices, the number of new apprenticeship contracts, unfilled vacancies and unsuccessful applicants. Taking into account the most recent data on business cycle expectations up to May 2020, we estimate that the coronavirusrelated decrease in firms' expectations about the business cycle can be associated with a predicted $9 \%$ decrease in firm demand for apprentices and an almost $7 \%$ decrease in the number of new apprenticeship positions in Germany in 2020 (-34,700 apprenticeship contracts; $95 \%$ confidence interval: +/- 8,800).

JEL classification: J23, J24, M53

Keywords: apprenticeship market, Covid-19, coronavirus, business cycle expectations

\author{
Samuel Muehlemann \\ LMU Munich \\ Munich School of Management \\ Geschwister-Scholl-Platz 1 \\ D-80539 Munich \\ Germany \\ muehlemann@bwl.Imu.de \\ and IZA Bonn \\ Bernhard Wittek \\ LMU Munich \\ Munich School of Management \\ Geschwister-Scholl-Platz 1 \\ D-80539 Munich \\ Germany \\ wittek@bwl.Imu.de
}

\author{
Harald Pfeifer \\ Federal Institute for Vocational \\ Education and Training Robert-Schuman- \\ Platz 3 D-53175 Bonn \\ Germany \\ harald.pfeifer@bibb.de \\ and ROA
}

\footnotetext{
* We thank Ralf-Olaf Granath, Lydia Lohmüller und Alexandra Uhly for the provision of and assistance with apprenticeship data, and Klaus Wohlrabe and Ludger Wößmann for helpful comments and suggestions with regard to the ifo Business Climate Index and the ifo Employment Barometer.
} 


\section{Introduction}

The Covid-19 pandemic is fundamentally altering outlooks in many parts of society. With the immediate health implications playing out across the globe, the economic impact is starting to show in labor markets as well. The United States has seen an unprecedented jump in unemployment figures to 21.0 million in May 2020, up from 7.1 million two months before (USBLS, 2020b) ${ }^{1}$. While Germany has not experienced comparably drastic developments so far, unemployment numbers rose from 2.3 million in March to 2.8 million in May (Federal Employment Agency, 2020a), economic expectations about the near future, here too, have turned decisively pessimistic. The effects of the expected downturn are likely to be felt differently across industries and segments of the population. In past crises, especially the young have suffered (see, e.g., Bell \& Blanchflower, 2011), albeit with marked differences between countries. In 2010, as much of the world was dealing with what has been termed the Great Recession, the unemployment rate for the youngest labor market cohort (15-24 year-olds) mounted to $41.6 \%$ in Spain, but was only at 9.9\% in Germany (European Commission, 2012). As researchers and policy makers seek explanations for such stark disparities, the use of apprenticeship systems, with a significant amount of on-the-job training, has frequently moved to the front. To what extent are such programs subject to the ups and downs of the economy and can they add to the resilience of a labor market during crises, for example, by facilitating the transition from school to full-time employment? To answer such questions, we direct our attention towards the impact of business cycle developments on the demand for apprentices. If such vocational education and training (VET) programs appear more robust to economic downturns, they may plausibly play a larger role in supporting the labor market as a whole. Thus far, research has outlined theoretical possibilities for both pro-cyclical effects, largely

\footnotetext{
${ }^{1}$ US unemployment numbers include a misclassification error reported by USBLS (2020a). This impacts data for March, April, and May. Corrected, likely increased, numbers were not yet available at the time of this writing.
} 
driven by reduced staffing needs during an economic downturn, as well as counter-cyclical outcomes, caused, for example, by lowered opportunity costs of training during less productive periods. Most empirical studies so far suggest a pro-cyclical, but small to moderate effect (see, e.g., Mühlemann, Wolter, \& Wüest, 2009). Furthermore, what matters in this regard, especially during more pronounced economic crises, seems to be more the longer term outlook, not the specific effect a downturn has on an individual company (Bellmann, Gerner, \& Leber, 2014). We seek to build on these prior findings and investigate how company expectations about business cycle developments influence apprenticeship provision. Subsequently, we attempt to project the likely short-term impact of Covid-19 on the German apprenticeship system, based on currently available information. We employ annual data on the number of firm-sponsored apprenticeship contracts between 2007 and 2018, processed by the Federal Statistical Office (DESTATIS) and provided by the Federal Institute for Vocational Education and Training (BIBB). To further differentiate the mechanisms of the expected labor market effect, we utilize additional data on the demand for apprentices (i.e., the sum of posted apprenticeship vacancies and unfilled positions) as well as the number of both successful and unsuccessful applicants for apprenticeship positions from the Federal Employment Agency (2007-2019). Expectations about business cycle developments are measured through the ifo Business Climate Index (BCI) and the ifo Employment Barometer (EB), two publicly available, monthly surveys among German firms, that provide particularly current and useful insights into company expectations about the business cycle (Sauer \& Wohlrabe, 2020; Wohlrabe, 2018). In investigating business cycle effects on this particularly relevant portion of the labor market and deriving a first estimate of the exceptional impact of the current Covid-19-linked downturn, we join a highly timely debate (see Lüthi \& Wolter, 2020b; Maier, 2020 for initial contributions), while there are still possibilities for policy makers and organizational stakeholders to react to what is unfolding. 
The following sections are organized as follows. We first provide a brief overview of the relevant attributes of the German apprenticeship system and the decisive role firms play therein. Subsequently, we offer a summary of the literature on business cycle effects on training provision. Chapters 4 and 5 follow with descriptive statistics and further details on our main variables, as well as the identification strategy used in our analysis. We then present our results and conclude with an outlook on the impact of current economic expectations on apprenticeship contracts this fall.

\section{The German apprenticeship system and its reliance on firms to offer training positions}

VET in Germany is offered through a publicly regulated "dual" system. It is referred to as "dual", as knowledge and skill acquisition does not only take place in vocational schools, but predominantly through practically oriented training and on-the-job learning at companies. Programs typically kick off in August or September each year and take students through two to three-and-a-half year apprenticeships, which result in qualifications for nationally recognized occupations. The specifics are heavily shaped by government regulations as well as negotiations between trade unions and employer associations ${ }^{2}$. Entry to this system is administered mainly through private contracts between apprentices and training firms. It is this decision of the firm to invest in training apprentices that is paramount for the aggregated amount of training provided in the economy as a whole, especially as young school graduates depend on further qualification to attain labor market access. We will discuss theoretical motivations for firms to offer training positions in greater detail below, but such motivations may be heavily affected by firms' expectations about the future business cycle. Once apprenticeships have begun, contractual training agreements can in effect not be terminated prematurely, unless for extraordinary circumstances. Dismissal is significantly easier during the first one to four months

\footnotetext{
${ }^{2}$ Hippach-Schneider and Huismann (2016) provide a useful and more comprehensive overview.
} 
of the apprenticeship, a period referred to as “probation”. Legal precedent has also long upheld that contracts can generally be cancelled without notice or justification prior to the commencement of the apprenticeship (Federal Labour Court, 1987). Once the apprenticeship has progressed beyond these initial stages, however, the legal and institutional commitment of the firm to complete the full, multi-year training period is strong (Dustmann \& Schönberg, 2012). Apart from organizational details, the training contract also includes the wages paid throughout the training period. While apprenticeship wages are in principle bound to collective agreements, the German apprenticeship market has seen the introduction of a regulatory minimum wage at the beginning of 2020. The wage floor was initially set at EUR 515 per month and designed to subsequently rise gradually to EUR 620 in 2023 (monthly wage in the first year of the apprenticeship program; BMBF, 2019). ${ }^{3}$ While contracts typically also contain an option to transition into regular employment, they formally end upon completion of the apprenticeship and publication of final examination results (BMBF, 2018). Hiring decisions of private companies are thus essential when it comes to how much training is actually provided to each cohort. We do not know when exactly those decisions are made, but, depending on the individual industry, recruitment cycles start as early as one year prior to the commencement of the apprenticeship program and go all the way through August or September (see, e.g., Azubiyo $\mathrm{GmbH}, 2020)^{4}$. Therefore, current, shorter-term expectations about economic prospects can be assumed to still factor heavily into this year's capacity considerations. This has principally been confirmed in previous empirical analysis as well (Dietrich \& Gerner, 2007).

\footnotetext{
${ }^{3}$ Research has described the minimum wage as an "obvious barrier to job training" (Leighton \& Mincer, 1981, p. 158) early on and argued that employers may, as a result, seek to increase employees' time allocated to productive activities (Hashimoto, 1982), which can be problematic during a recession. While this development is not the focus of our undertaking, the cost increases it may potentially represent, could conceivably add to the current dynamic in some cases.

${ }^{4}$ Moreover, the Federal Employment Agency (Bundesagentur für Arbeit) publishes monthly statistics on the number of advertised vacancies, registered applicants, and successfully signed contracts in the German apprenticeship market (https://statistik.arbeitsagentur.de/Navigation/Statistik/Statistik-nach-

Themen/Ausbildungsstellenmarkt/Ausbildungsstellenmarkt-Nav.html) for the months of January to September.
} 


\section{Relevant literature}

Research has identified two relevant underlying motivations for companies to hire apprentices: productivity, i.e. reasons driven by today's production requirements, or investment, i.e. reasons driven by tomorrow's production requirements (Lüthi \& Wolter, 2020a; Merrilees, 1983; Wolter \& Ryan, 2011). The production motive (Lindley, 1975) looks at apprentices essentially as just another input factor in the production process, a substitute for other labor, albeit often a less effective one. There may still be some investment period necessary at the beginning of training, but firms hire apprentices predominantly because of the net benefit they incur through the productive contributions of apprentices relative to their wages. The more forward-looking investment variant (Stevens, 1994) has its roots in Becker's (1964) human capital theory and looks at apprentices mainly as future skilled workers. In this regard, firms are willing to incur net costs during the initial training phase, in order to benefit in the future, for example, from secured or cheaper access to skilled labor. Prior research contributions have established certain characteristics of the labor market, such as information asymmetries (Acemoglu \& Pischke, 1999), mobility costs and a resulting reluctance to relocate (Beckmann, 2002; Harhoff \& Kane, 1997), or rigidities associated with trade unions and works councils (Dustmann \& Schönberg, 2009; Kriechel, Mühlemann, Pfeifer, \& Schütte, 2014), which may allow companies to suppress wage levels around the provision of training and recover their investment. Cost-benefit analyses suggest that investment motives play a decisive role for German firms in their considerations around the provisions of apprenticeships, driven significantly by labor market regulations (Mühlemann, Pfeifer, Walden, Wenzelmann, \& Wolter, 2010). The investment motive, thus, helps to explain findings in empirical studies that have demonstrated a willingness by German firms to incur substantial net costs during vocational training programs (Dionisius et al., 2009). Based on these motivations, the effect of business cycle developments on training provision remains ambiguous ex-ante. Naturally, an economic downturn may lead to fewer transactions, lowered productivity and, therefore, a decrease in demand for labor, including apprentices. 
Furthermore, as unemployment increases, so does the availability of skilled labor in the labor market, which may alter investment considerations and cause a pro-cyclical response of apprenticeships to business cycles. If, on the other hand, skilled workers can be replaced by apprentices as a means to lower costs, a counter-cyclical movement could also seem plausible. Moreover, increasing training efforts during an economic slump can represent a prudent strategy from an investment perspective, if opportunity costs for training tasks of skilled employees are lowered and potential rewards for increased productivity are high, once the economy picks up again (Brunello, 2009). Additionally, exit options may be relatively poor for apprentices during a recession, which may lower the perceived risks around a firm's training investments (Bellmann et al., 2014). Likely, the temporal dimension of the expected downturn plays a significant role. In most cases, training involves an up-front investment, especially during the early phases of apprenticeships, which may later be recovered by firms (Wolter \& Ryan, 2011). If uncertainty about the immediate future is sufficiently high, firms may be more hesitant to incur such investment costs, even if productivity benefits from training exceed initial expenses over the course of the full contract duration. Additionally, in Germany, an estimated $62 \%$ of training costs are wage costs of apprentices and only about $23 \%$ of training costs are associated with the wage costs of the instructors (Schönfeld, Jansen, Wenzelmann, \& Pfeifer, 2016), suggesting that opportunity cost reduction plays only a secondary role. To the extent that a recession is expected to be of short duration, however, firms may still hire new apprentices in 2020 if they expect that they will need to fill skilled-worker positions in by 2023. Of course, even though our focus is on the demand side, with the firm's decision to provide apprenticeships, it should not be left unmentioned that there is a supply side to this problem as well. Here, too, several effects are conceivable, as unemployment increases the supply of applicants for skilled positions or, on the other hand, interest in apprenticeship positions may decrease, as school graduates opt for further schooling instead of attempting to enter the VET labor market in times of high unemployment (Weßling, Hartung, \& Hillmert, 2015). 
Based on these theoretical foundations, empirical studies mostly describe a positive (procyclical) effect of business cycle developments on the number of apprenticeship contracts offered. This effect, however, is estimated to be small to moderate in size. Brunello (2009) provides a useful overview of empirical research. Among others, pro-cyclical behavior of apprenticeship markets has been shown for Norway (Askilden \& Nilsen, 2005), Denmark (Westergaard-Nielsen \& Rasmussen, 1999), or the United Kingdom (Merrilees, 1983), predominantly using income, investment, order backlog, or unemployment statistics as independent variables. More recently, the Swiss cantonal context has attracted significant attention of researchers, again suggesting a pro-cyclical effect of economic developments on apprenticeships (Schweri \& Müller, 2008). The relationship is estimated to be small and largely overshadowed by more important demographic drivers (i.e. number of school graduates; Mühlemann et al., 2009). Lüthi and Wolter (2020a) provide the most recent contribution that analyzes Swiss data. While they conclude pro-cyclical effects as well, their evaluation provides a more nuanced picture. Emphasizing the importance of longer-term expectations, they argue that unemployment changes largely only lead to postponing of training activities, while GDP changes have a more sustained, moderate effect. Compared to Germany, however, the Swiss labor market may put greater emphasis on productivity-related training motivations (Mühlemann et al., 2010), leaving us with some question marks regarding the transferability of these findings to our empirical context.

When looking specifically at the German labor market, research has yet to produce conclusive interpretations of empirical data. In what is probably the study covering the longest time period to date, Baldi, Brüggemann-Borck, and Schlaak (2014) investigate business cycle related drivers of apprenticeship contracts offered in Germany between 1999 and 2012. Their analysis shows that the effects of income growth and unemployment rates are small to none during what they refer to as "normal times" (p. 11). They do suggest, however, that this picture is a clearer one during more pronounced downturns, such as the 2008 financial crisis and its aftermath. 
Similar results are reported by Bellmann et al. (2014), who also investigate the impact of the 2008/2009 downturn on German apprenticeship numbers. Their findings indicate that while training activities declined during the crisis years, they did so irrespective of whether the firm was directly affected by the recession, driven more by the general macroeconomic outlook. They also argue that apprenticeships seem to be more robust to business cycle influences, based, however, on a short-term difference-in-differences estimation. Both contributions suggest that effects depend markedly on expectations about the general severity and duration of the economic downturn. Dietrich and Gerner (2007) offer the most directly applicable precedent to our study. In contrast to the previously mentioned publications, they do not look at actual economic developments, as measured by (lagged) income growth or unemployment rates, but instead look at the relationship between short-term business expectations and training provision. They show a pro-cyclical effect on the amount of training provided by firms, arguing mainly based on corresponding changes in assumptions about future transaction and opportunity cost.

We build on these prior contributions and offer the first long-term empirical analysis of business cycle effects on the German apprenticeship market that includes both the period of the Great Recession and initial data on economic expectations in the anticipated downturn caused by the Covid-19 pandemic. Lüthi and Wolter (2020b) have put forward a first projection of likely, decisively negative impacts of current economic developments on the Swiss apprenticeship market. They argue that especially bankruptcies may push the decrease of offered training positions beyond what we have observed during past downturns. Maier (2020) develops a first scenario analysis for the German context, highlighting in particular the unevenness of the (again pro-cyclical) effect of ongoing developments. We offer an initial view of what can be expected for the German VET labor market based on current business cycle expectations. 


\section{Data and variable construction}

In this section we provide information and descriptive statistics for our main variables of interest: demand and supply for apprentices and the resulting number of new annual apprenticeship contracts in Germany, unfilled vacancies and unsuccessful applicants in the apprenticeship market, as well as two measures of company business cycle expectations. We further include descriptive statistics on the number of school leavers.

\section{ifo Business Climate Index (BCI) and ifo Employment Barometer (EB)}

Our main explanatory variable captures the expectation of firms about the business cycle at a particular point in time, as surveyed on a monthly basis by the ifo Institute. Figure 1 shows the development of our two indicators of interest, the Business Climate Index (BCI) and the Employment Barometer (EB) from January 2005 onwards. The BCI indicates companies' assessment of the current business climate and their expectations for the next six months. It is one of Germany's most relevant indicators about business cycle developments and a valid predictor of future GDP. The EB measures firms' employment plans for the following three months and may therefore also be a good predictor of firm decisions to hire apprentices.

Both indices reflect a significant drop during 2008 (the start of the financial crisis) and illustrates the subsequent recovery. ${ }^{5}$ In recent years, business cycle expectations continued to increase until August 2018, when both the BCI and the EB reached their peaks. They then decreased steadily but continuously, until the start of the coronavirus outbreak and the associated lockdown in Germany in March 2020. The BCI (EB) subsequently dropped to 74.3 (86.3) points in April 2020, their lowest value since January 2005. In May 2020, the indices

\footnotetext{
${ }^{5}$ However, the firms' employment plans, as measured in the EB, tend to be less volatile compared to the assessment of the business climate, which can be explained by frictions in the German labor market (employment protection legislation) as well as the possibility for firms to apply for short-time work compensation that typically prevent firms from immediate layoffs during an economic crisis.
} 
recovered slightly to 79.5 (88.6) points. Thus, the current average BCI (EB) stands at 76.9 (87.3) for the second quarter, 21.7 (13.3) points lower than the second quarter in 2019.

As we only observe the yearly number of apprenticeship contracts, the indices need to be redefined on an annual basis as well. Table 2 illustrates the average annual change in BCI and $\mathrm{EB}$, when considering the average of the first quarter $\left(\overline{B C I}_{Q 1}\right)$, the second quarter $\left(\overline{B C I}_{Q 2}\right)$, or the first six months $\left(\overline{B C I}_{Q 1+Q 2}\right)$ of a particular year. As shown below, annual differences appear qualitatively rather similar. Our empirical estimates do not depend strongly on the exact definition of the relevant observation period to compute $\Delta \overline{B C I}$ (and $\Delta \overline{E B}) .^{6}$

Figure 1: ifo Business Climate Index and ifo Employment Barometer (January 2005 to May 2020)

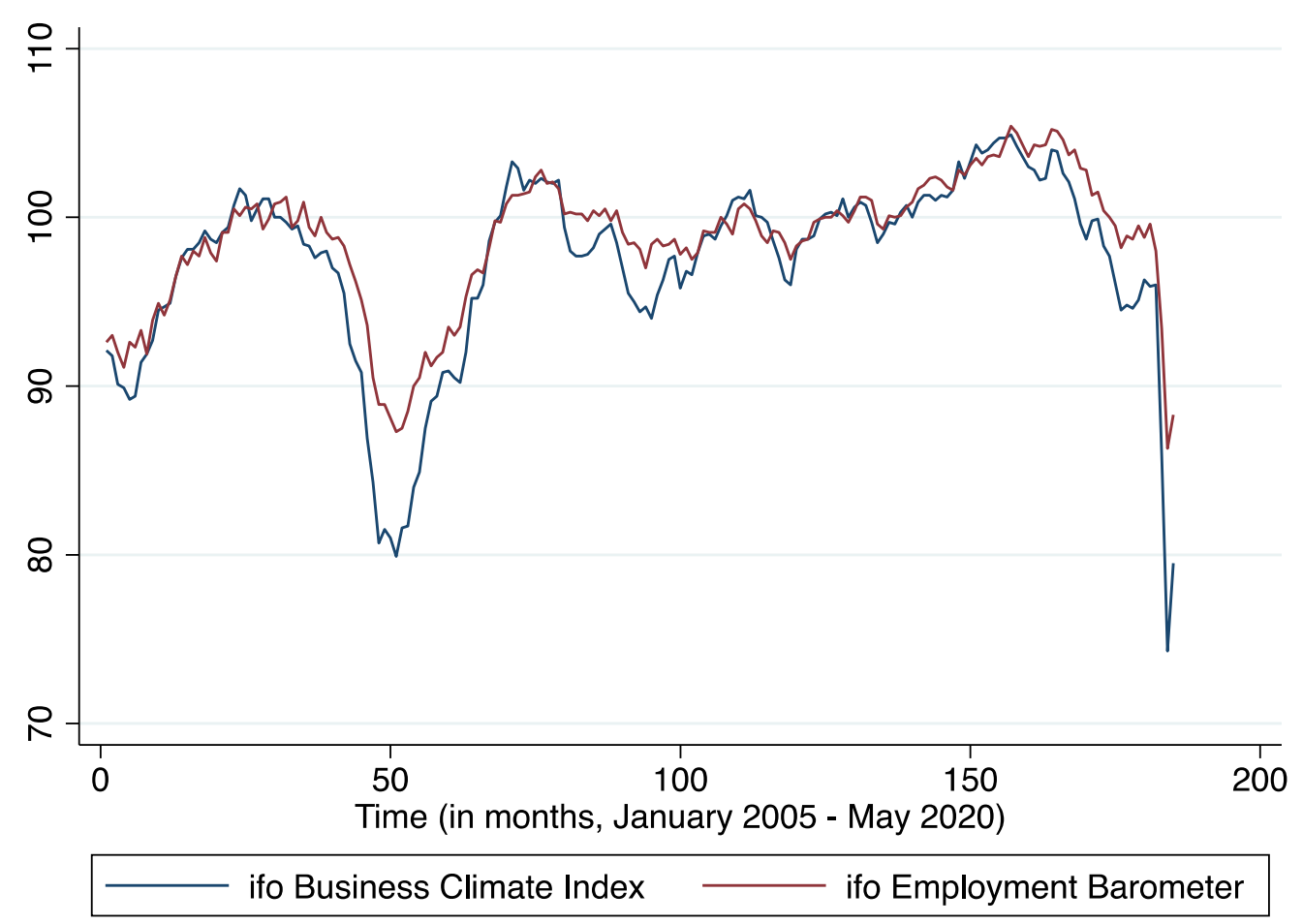

Source: ifo Business Climate Index (ifo Geschäftsklimaindex), normalized to the average of the year 2015, https://www.ifo.de/en/survey/ifo-business-climate-index), and ifo Employment Barometer (ifo Beschäftigungsbarometer), normalized to the average of the year 2015, https://www.ifo.de/en/survey/ifoemployment-barometer; see Sauer and Wohlrabe (2020) for detailed methodologies.

\footnotetext{
${ }^{6}$ For reasons of brevity, we refrain from always reporting all of our results of both $\mathrm{BCI}$ and $\mathrm{EB}$, but we include a model that uses the EB as an independent variable in our main regression tables in section 6 (Table 2, Table 4, and Table 5). As it turns out, our results are very similar and robust irrespective of which of the two indicators we use in our regression models.
} 
Table 1: Yearly changes in the ifo Business Climate Index (BCI) and the ifo Employment Barometer

$(\mathrm{EB} ; 2005-2020)$

\begin{tabular}{ccccccccc}
\hline Year & $\overline{B C I}_{Q 1}$ & $\overline{B C I}_{Q 2}$ & $\overline{B C I}_{Q 1+Q 2}$ & $\Delta \overline{B C I}_{Q 1}$ & $\Delta \overline{B C I}_{Q 2}$ & $\Delta \overline{B C I}_{Q 1+Q 2}$ & $\overline{E B}_{Q 2}$ & $\Delta \overline{E B}_{Q 2}$ \\
\hline 2005 & 91.3 & 89.5 & 90.4 & $\mathrm{n} / \mathrm{a}$ & $\mathrm{n} / \mathrm{a}$ & $\mathrm{n} / \mathrm{a}$ & 92.0 & $\mathrm{n} / \mathrm{a}$ \\
2006 & 97.4 & 98.6 & 98.0 & 6.1 & 9.1 & 7.6 & 98.2 & 6.2 \\
2007 & 100.5 & 100.7 & 100.6 & 3.1 & 2.1 & 2.6 & 100.0 & 1.8 \\
2008 & 97.8 & 96.4 & 97.1 & -2.7 & -4.3 & -3.5 & 98.6 & -1.4 \\
2009 & 80.8 & 82.4 & 81.6 & -17.0 & -14.0 & -15.5 & 88.7 & -9.9 \\
2010 & 90.9 & 95.5 & 93.2 & 10.1 & 13.0 & 11.6 & 96.7 & 8.1 \\
2011 & 101.9 & 102.1 & 102.0 & 11.0 & 6.7 & 8.8 & 102.3 & 5.6 \\
2012 & 98.8 & 98.4 & 98.6 & -3.1 & -3.8 & -3.4 & 99.8 & -2.5 \\
2013 & 97.2 & 96.4 & 96.8 & -1.7 & -2.0 & -1.8 & 97.8 & -1.9 \\
2014 & 101.1 & 100.6 & 100.8 & 3.9 & 4.2 & 4.0 & 99.7 & 1.9 \\
2015 & 98.8 & 100.1 & 99.5 & -2.3 & -0.4 & -1.4 & 100.0 & 0.2 \\
2016 & 99.1 & 99.9 & 99.5 & 0.3 & -0.3 & 0.0 & 100.1 & 0.1 \\
2017 & 101.4 & 103.0 & 102.2 & 2.3 & 3.1 & 2.7 & 102.8 & 2.7 \\
2018 & 104.2 & 102.7 & 103.5 & 2.9 & -0.3 & 1.3 & 104.0 & 1.2 \\
2019 & 99.4 & 98.6 & 99.0 & -4.9 & -4.0 & -4.4 & 100.6 & -3.4 \\
2020 & 92.6 & 74.3 & 88.0 & -6.8 & $-21.7 *$ & $-12.68^{*}$ & 87.3 & $-13.3 *$ \\
\hline
\end{tabular}

Source: ifo Business Climate Index (ifo Geschäftsklimaindex, https://www.ifo.de/en/survey/ifo-business-climateindex) and ifo Employment Barometer (ifo Beschäftigungsbarometer, https://www.ifo.de/en/survey/ifoemployment-barometer). *Q2 only includes April and May in 2020.

\section{Demand and supply of apprentices}

A firm's demand for apprentices is defined as the sum of the number of apprenticeship contracts and unfilled vacancies that firms post in a given year. ${ }^{7}$ Figure 2 shows that the demand for apprentices correlates strongly with the business climate in the period between 2007 and $2019 .^{8}$ In particular, the decrease in the demand for apprentices as a result of the financial crisis in

\footnotetext{
${ }^{7}$ Note that unfilled vacancies only include registered vacancies with the Federal Employment Agency, and not the entire population of unfilled vacancies in Germany. Although no statistics exists that include the population of all statistics in Germany, registered vacancies with the Federal Employment Agency likely correlate strongly with the total number of vacancies in Germany over time.

${ }^{8}$ The state-level data is published by the Federal Employment Agency and refers to the 30th of September of each year. Note that contrary to this, all data at the occupation-level (Table 5, Table A1-A2, Tables A4-A6) refer to the 31st of December of each year and, thus, also cover all contracts that were signed or terminated between the 30th of September and the end of the respective year.
} 
2009 and 2010 is clearly visible, as well as the subsequent increase during the economic recovery.

The supply of apprentices is defined as the number of individuals that apply for an apprenticeship position in a particular year. ${ }^{9}$ Figure 3 shows that the supply correlates strongly with the number of school leavers. However, other factors such as the regional share of high school graduates and individual preferences may also play an important role.

Figure 2: Demand for apprentices, ifo Business Climate Index (BCI), and ifo Employment Barometer $(\mathrm{EB} ; 2007-2019)$

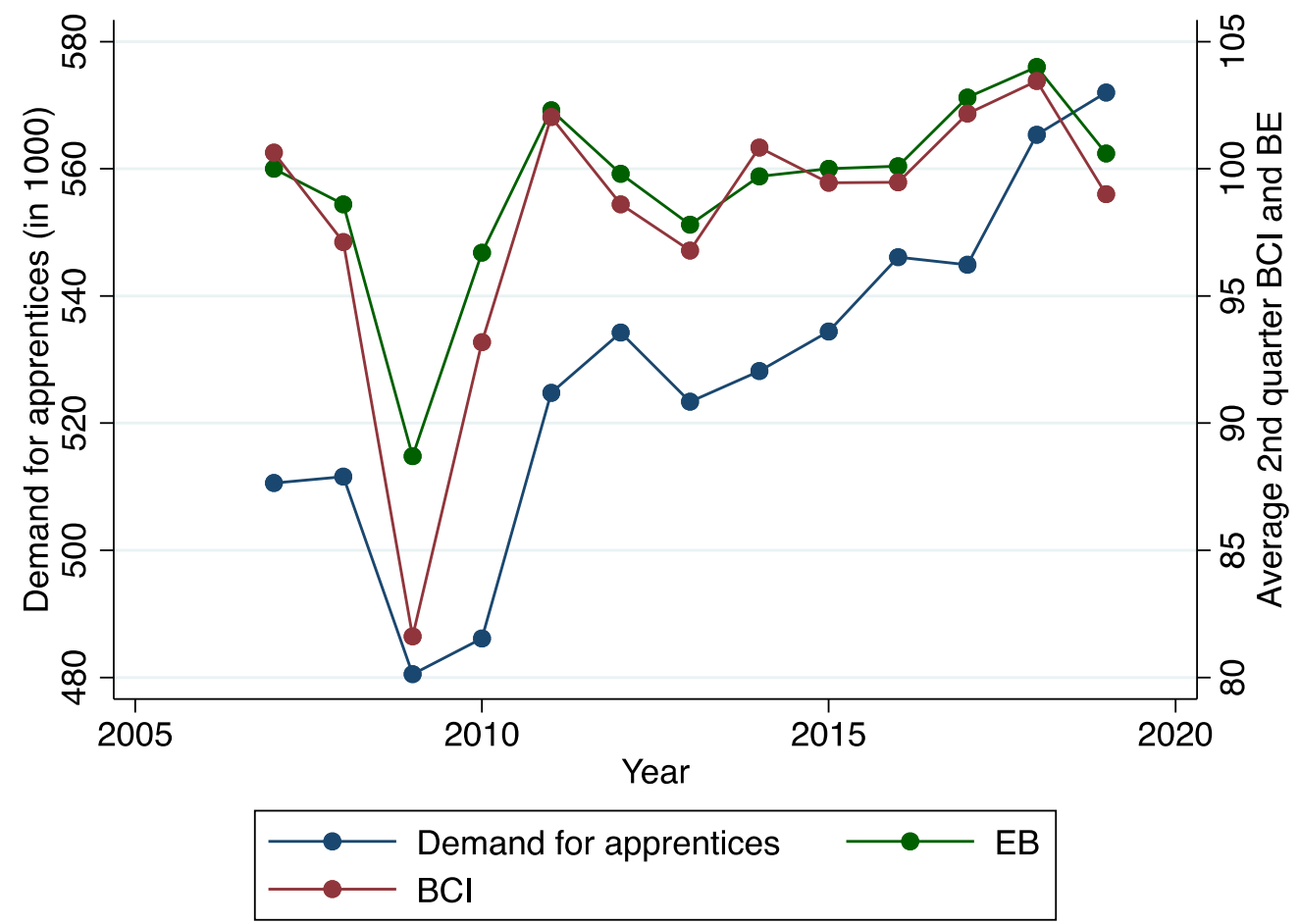

Source: ifo Business Climate Index (ifo Geschäftsklimaindex, https://www.ifo.de/en/survey/ifo-business-climateindex), and ifo Employment Barometer (ifo Beschäftigungsbarometer, https://www.ifo.de/en/survey/ifoemployment-barometer); Federal Employment Agency (statistics on the apprenticeship market).

\footnotetext{
${ }^{9}$ Note that the supply is defined as the sum of the number of apprenticeship contracts and the number of unsuccessful applicants who are registered with the Federal Employment Agency, and not the entire population of unsuccessful applicants in Germany.
} 
Figure 3: Supply of apprentices and number of school leavers (2007-2019)

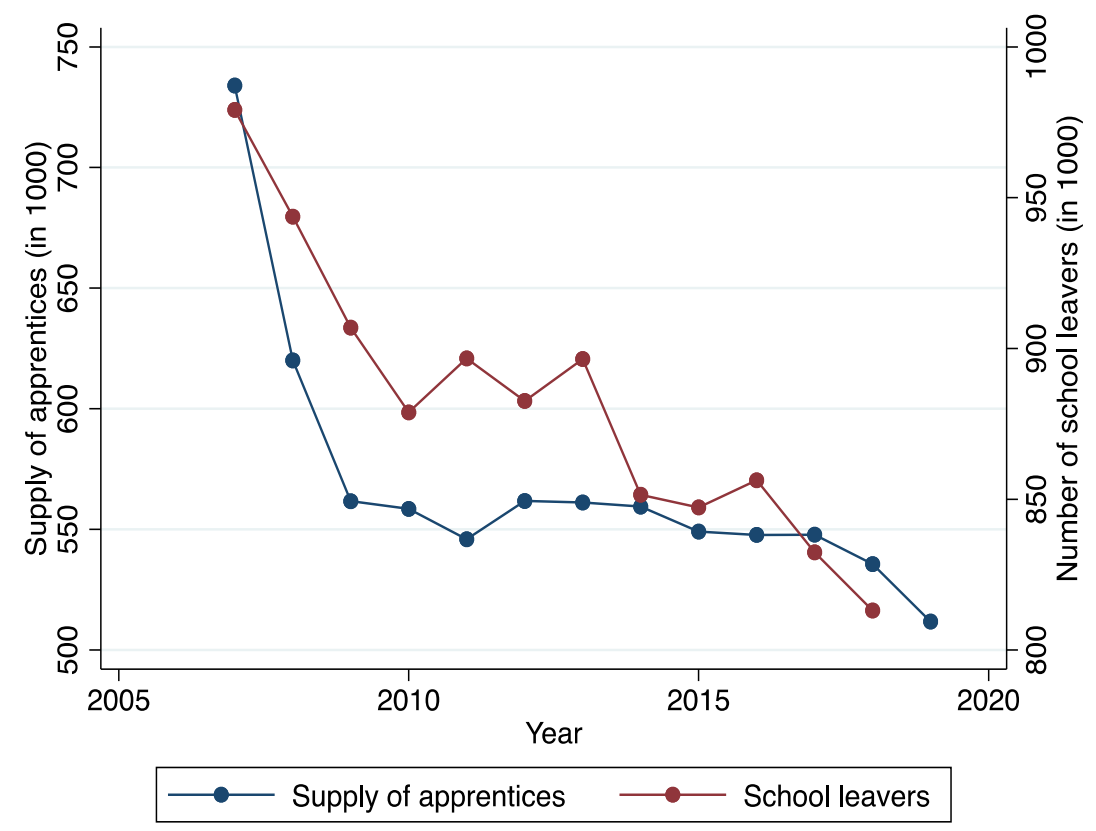

Source: Federal Employment Agency (statistics on the apprenticeship market). Federal Statistical Office (school leavers from general schools, excluding vocational schools)

\section{New apprenticeship contracts}

In Germany, some firms already sign apprenticeship contracts early in the year, while others only find a suitable apprentice shortly before the start of training in August or September ${ }^{10}$. Since many of the temporal aspects of the recruiting process are unclear or vary between firms and industries, it is not possible to precisely model in what month a firm's business expectations are most relevant when it comes to hiring apprentices. Furthermore, as we have described above, a firm can terminate apprenticeship contracts rather easily during the first one to four months of training and prior to the commencement of training. For that reason, we also estimate a regression to test whether changes in the Business Climate Index are associated with subsequent changes in the number of prematurely terminated apprenticeship contracts, however, without significant results (cf. Table A3).

\footnotetext{
${ }^{10}$ The exact start of an apprenticeship program varies by state. By May 2020, a total of 465,700 apprenticeship positions were advertised by training firms (-9.1\% compared to 2019) and 204,000 individuals had successfully signed an apprenticeship contract ((-14.6\% compared to 2019, cf. Federal Employment Agency, 2020b).
} 
Figure 4 shows the development of the annual number of firm-sponsored apprenticeship contracts since 2007 and includes all apprenticeship contracts as of 31 December 2018. Thus, any contract that was terminated after or even before the start of training would not be included in our data. The data further do not include publicly financed apprenticeship positions for people with disabilities, because their provision and governing regulations follow different principles compared to "regular" apprenticeship positions. Figure 4 illustrates that the number of firm-based apprenticeship contracts in Germany decreased from over 600,000 in 2007 to about 500,000 in 2016 and that this development correlates strongly with the annual number of school leavers. Moreover, we can observe an unusually strong decline in the number of apprenticeship contracts following the financial crisis from 2008 to 2009, when apprenticeships fell by $7.7 \%$ year over year. While demographic change (fewer school leavers) likely accounts for part of the decrease in the number of apprenticeship contracts throughout the observed period, the magnitude of the decline during the crisis years 2008 and 2009 suggests that economic conditions likely play a role as well. However, based on descriptive statistics, we cannot clearly distinguish the influence of demographic changes, business cycle fluctuations, other structural developments at the industry-level, or regional differences (such as the wellknown matching problems that routinely leads to unfilled vacancies and unsuccessful applicants) by only looking at aggregate numbers for Germany. 
Figure 4: Number of firm-sponsored apprenticeship contracts and school leavers (2007-2018)

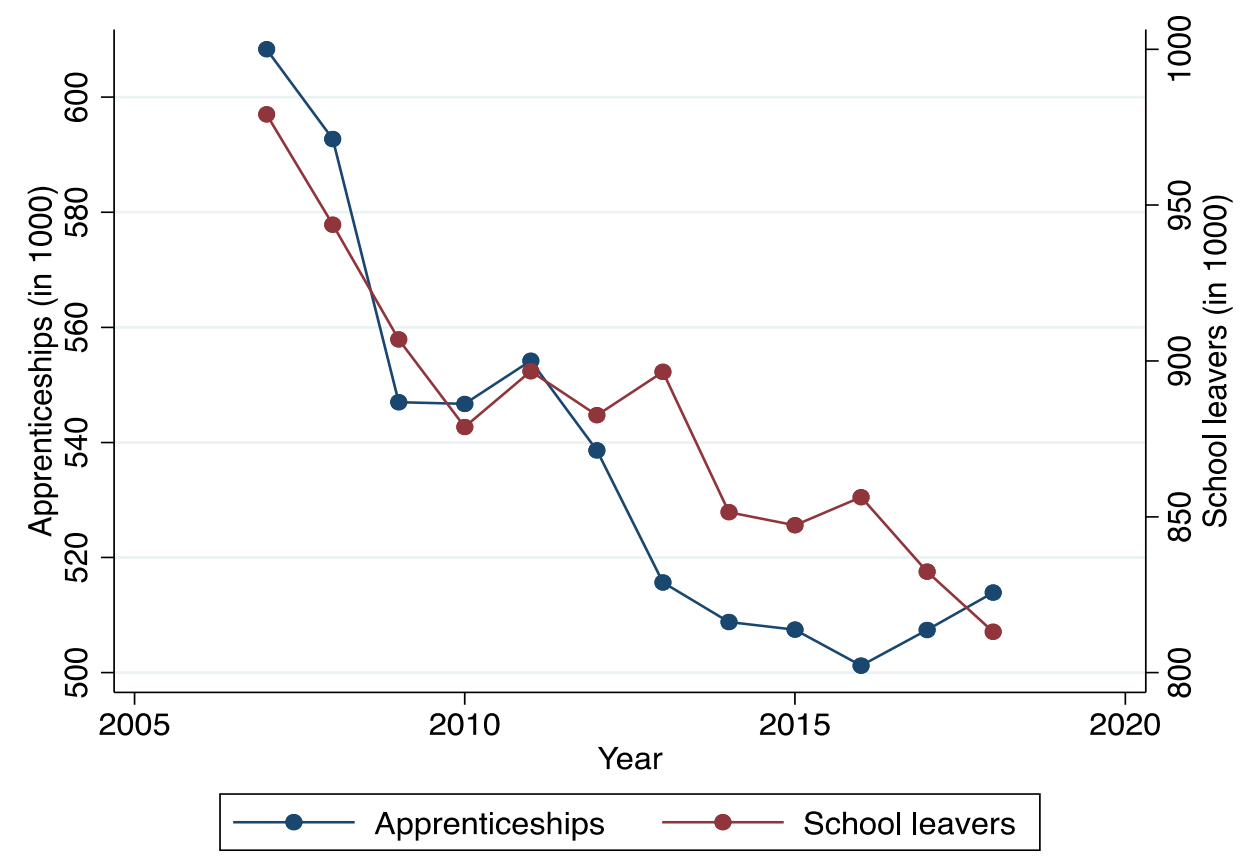

Sources: Vocational Training Statistics of the statistical offices of the federal and state governments; Federal Statistical Office (school leavers from general schools, excluding vocational schools)

For our empirical analysis we use the register of all apprenticeship contracts per year, starting in 2007. The contract information is collected by the regional chambers of commerce and then processed to the Federal Statistical Office. The final dataset is provided by the Federal Institute for Vocational Education and Training $(\mathrm{BIBB})^{11}$. Reporting is mandatory for the regional chambers of industry and commerce, so that the register represents a full sample of all apprenticeships in Germany. Data include characteristics of the apprentice (contract holder) as well as regional and occupation-specific details. With this information, we construct a panel dataset that includes the number of new contracts in a given occupation, the state (Bundesland), and the contract year. A total of 321 occupations are recorded in the dual training system for all 16 federal states over a period of 12 years (from 2007 until 2018) ${ }^{12}$. The average number of

\footnotetext{
${ }^{11}$ For more details on the data contents see Destatis (2012). For a discussion of the research potential of this data see Rohrbach-Schmidt and Uhly (2016).

${ }^{12}$ Microdata for 2019 were not yet available at the time of publication.
} 
apprenticeships per occupation by state is reported in the appendix (Tables A1 and A2). We also match the number of school leavers at the state-year level, in order to control for regional demographic change in our empirical analysis.

Figure 5: Number of apprenticeships by prior educational attainment (2007-2018)

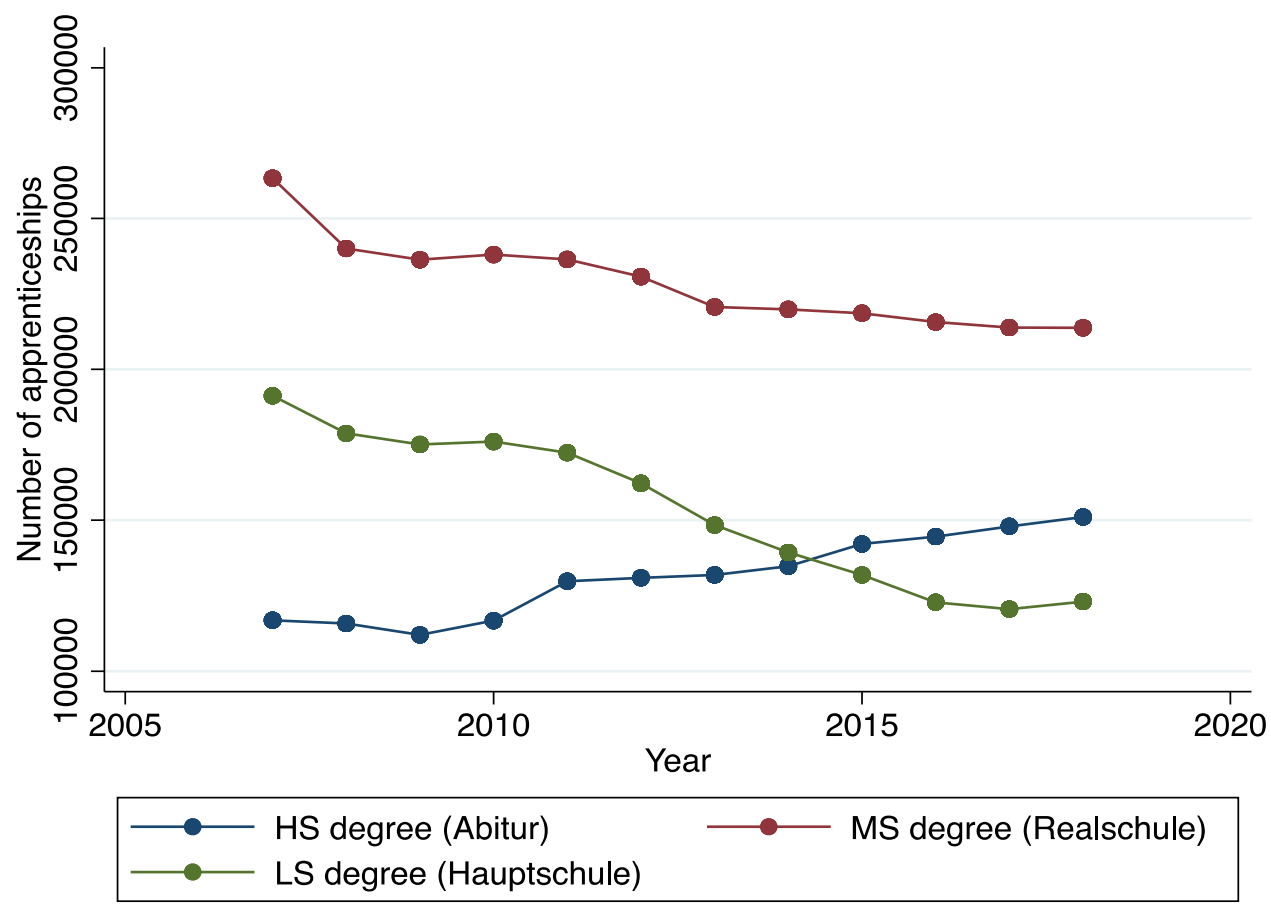

Source: Vocational Training Statistics of the statistical offices of the federal and state governments

A further notable characteristic of the German apprenticeship market is the difference in the development of apprenticeship contracts by applicants' prior educational attainment, as presented in Figure 5. A clear negative trend can be observed in the number of apprenticeship contracts for lower-school graduates (LS, Hauptschule) and graduates with a mid-level school qualification (MS, Realschule). Conversely, the number of apprenticeship contracts with individuals who have a high school degree (HS, Abitur), which also allows them to study at a German university, increased continuously from 2009 to 2018 . With this in mind, we carry out 
our analysis at the state-level and further account for the occupational field at the 3-digit level. Differentiation at the occupational level is important, because there is substantial heterogeneity across apprenticeship occupations with regard to educational requirements, training duration and future employment prospects (e.g., expected wage that an apprentice will earn as a skilled worker, as well as development opportunities). We further include distinct models, separated by educational subset of our sample (cf. Tables A4-A6).

Frictions in the German apprenticeship market: the dynamics of unfilled vacancies and unsuccessful applicants

So far, the descriptions provided are still missing one important dynamic: matching. The number of observed apprenticeship contracts in a particular year does not simply depend on aggregate demand and supply. Instead, it is crucial that the type of demand matches the type of supply in a given geographical or occupational area of the labor market. Resulting frictions, expressed in the number of unfilled vacancies and unsuccessful applicants, are important pieces of information that should be taken into account in the context of business cycle fluctuations. Figure 6 highlights that in the year following the financial crisis, both the number of unfilled apprenticeship vacancies as well as the number of unsuccessful applicants for apprenticeship positions were rather low, at less than 20,000 (unfilled vacancies) and 15,000 (unsuccessful applicants) respectively. In light of the economic recovery that started in 2010 and reached its peak in 2011, the number of unfilled vacancies began to increase, while the number of unsuccessful applicants initially dropped. As the economy remained strong through 2018, the number of unfilled vacancies increased substantially and came close to reaching 58,000 in 2018 . At the same time, however, the number of unsuccessful applicants started to increase, despite the overall number of school leavers in Germany declining - an indication for an increased matching problem in the German apprenticeship market. 
Figure 6: Number of unfilled vacancies, unsuccessful applicants, ifo Business Climate Index (BCI), and ifo Employment Barometer (EB; 2007-2019)

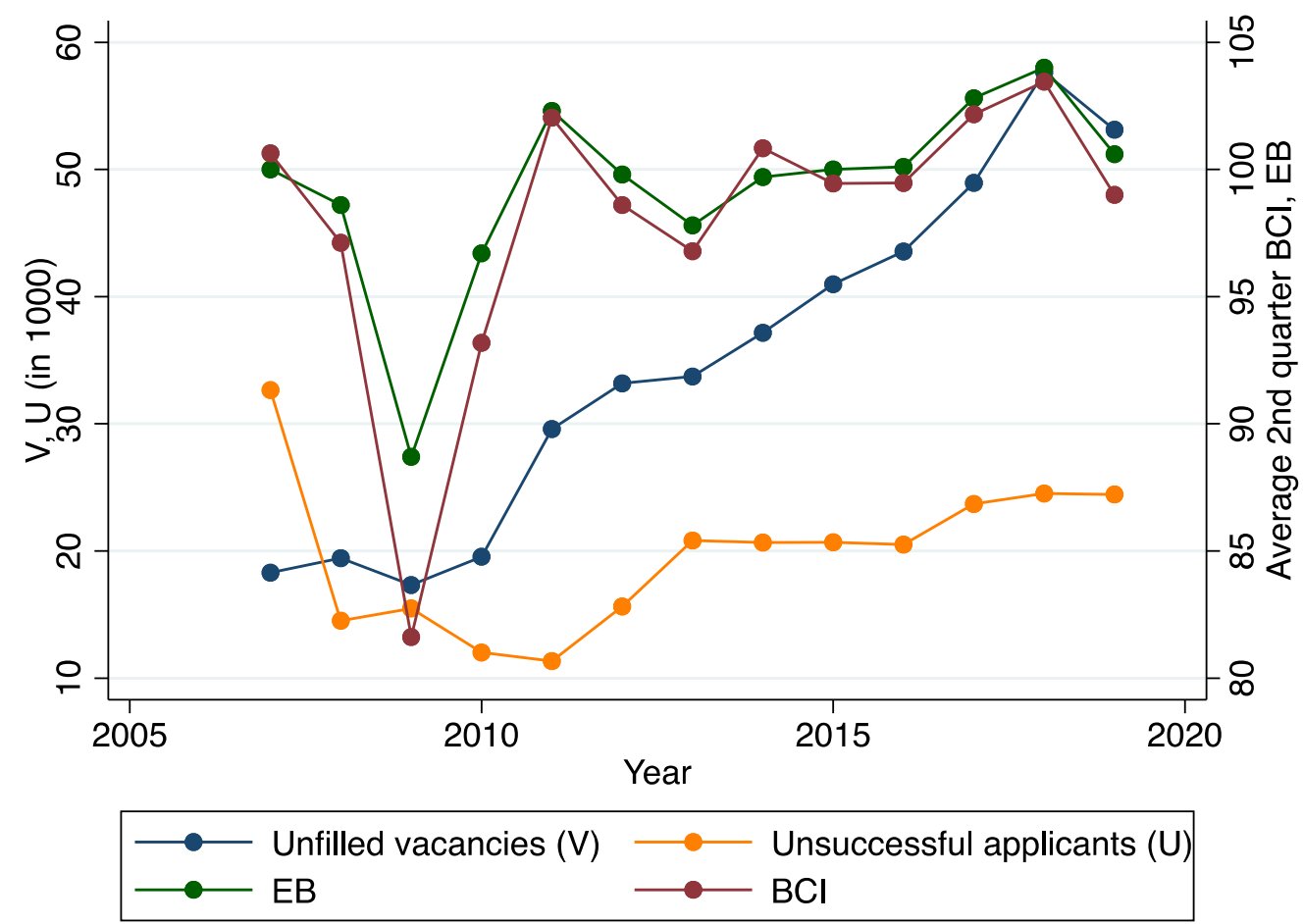

Source: Apprenticeship market statistics 2007-2019, Federal Employment Agency (2020b), ifo Business Climate Index and ifo Employment Barometer.

A more detailed analysis at the state-level reveals that the dynamics differ quite strongly across states. States in the South and East of Germany did not experience an increase in the share of unsuccessful applicants, while North Rhine-Westphalia, Hesse, Rhineland-Palatinate, as well as Hamburg and Schleswig-Holstein experienced increased matching problems, as both the share of unfilled vacancies and the share of unsuccessful applicants increased from 2010-2018 (Figures A1-A4). Moreover, the level of unsuccessful applicants is lowest in the South of Germany (Baden-Wurttemberg and Bavaria) ${ }^{13}$.

\footnotetext{
${ }^{13}$ Within states, there are also some differences in the development of unfilled vacancies that depend on occupational fields (crafts sector vs. industry and trade), as indicated in Figures A5-A8.
} 
In addition to the described issues, there may also be many young applicants that fall outside of the definition of "unsuccessful", as they were able to secure an alternative to an apprenticeship contract (e.g., a preparation year in order to close any skill gaps or other schoolbased alternatives). In 2019, on top of roughly 25,000 unsuccessful applicants, another 20,000 individuals were still actively searching for an apprenticeship position despite having found an alternative to an apprenticeship (Federal Employment Agency, 2020b).

\section{Identification strategy}

We follow Mühlemann et al. (2009), who estimate changes in the number of annual apprenticeships at the state-level. However, in our data, we are able to observe the number of apprenticeship positions not only for a particular state, but we also observe the occupational field within each state at the 5-digit level. Thus, our main dependent variable of interest is the logarithm of new apprenticeships in occupation $o$, state $s$ and year $t$ :

$$
a_{o s t}=v_{o s}+\mathbf{x}_{s t}^{\prime} \beta+\varepsilon_{\text {ost }}
$$

where $v_{\text {so }}$ accounts for unobserved heterogeneity at the state- and occupation-level, and $\mathbf{x}$ includes our main variable of interest $\left(\overline{B C I}_{t Q 2}\right)$, as well as the logarithm of graduates $g_{s t}$ from general schools in state $s$ in period $t$. The error term is represented by $\varepsilon_{\text {ost }}$.

We estimate first-differences regression models to account for unobserved factors at the stateand occupation-level. The differences in new annual (log) apprenticeship contracts are given by:

$$
a_{o s t}-a_{o s t, t-1}=\left(\mathbf{x}_{s t}-\mathbf{x}_{s t, t-1}\right)^{\prime} \beta+\left(\varepsilon_{o s t}-\varepsilon_{o s t-1}\right)
$$

To obtain consistent estimates, it is required that $E\left[\left(\varepsilon_{\text {ost }}-\varepsilon_{\text {ost }-1}\right) \mid\left(\mathbf{x}_{s t}-\mathbf{x}_{s t, t-1}\right)\right]=0$. This assumption is weaker compared to the strong exogeneity condition that is required to estimate an alternative fixed effects model, where $E\left[\varepsilon_{\text {ost }} \mid \mathbf{x}_{s 1}, \ldots, \mathbf{x}_{S T}\right]=0$. We estimate first-differences 
using OLS and report heteroskedasticity and autocorrelation-robust standard errors. We also include interaction terms of linear trends for 3-digit occupations and for East Germany, in order to account for occupation-specific trends and the stronger decrease in the number of apprenticeships in recent years in East German states (Tables A1 and A2).

Moreover, using the same framework, we estimate the demand for apprentices and the determinants of unfilled vacancies and unsuccessful applicants for the period 2007 to 2019, using state-level data from the Federal Employment Agency (2020b). In particular, we estimate first differences in the log demand for apprentices that is given by

$$
d_{s t}-d_{s t, t-1}=\left(\mathbf{x}_{s t}-\mathbf{x}_{s t, t-1}\right)^{\prime} \beta+\left(\varepsilon_{s t}-\varepsilon_{s t-1}\right)
$$

where $v_{s t}$ denotes the $\log$ demand for apprentices in state $s$ at time $t$. Similarly, we estimate additional models using the log number of unfilled vacancies $\left(v_{s t}\right)$ and unsuccessful applicants $\left(u_{s t}\right)$ as dependent variables.

\section{Results}

The following section reports the results of our first-differences regressions. Our main interest is to quantify the association between $\mathrm{BCI}$ or $\mathrm{EB}$ and the number of new apprenticeship contracts, conditional on controlling for the number of school graduates. Therefore, our key independent variables are $\Delta \overline{B C I}_{Q 2 t, Q 2 t-1}$ and $\Delta \overline{E B}_{Q 2 t, Q 2 t-1}$, which capture annual changes between second quarter average values of BCI and EB. We estimate the effect of these explanatory observations in subsequent models on log annual changes in the demand for apprentices, the number of unfilled vacancies and unsuccessful applicants, as well as in the number of apprenticeship contracts. 


\section{Demand for apprentices and business cycle expectations}

We first regress state-level demand for apprentices on $\mathrm{BCI} / \mathrm{EB}$ and find, as expected, a positive and statistically significant association. According to Model 3, a 1-point increase in the BCI in period $t($ period $t-1)$ is associated with a $0.37 \%(0.29 \%)$ increase in the demand for apprentices. To illustrate the economic significance, consider the demand for apprentices in 2009 compared to 2008: the BCI dropped by 14 points from 2008 to 2009, and by 4.4 points from 2007 to 2008 .

Table 2: First-differences regression, demand for of apprentices (state-level, 2007-2019)

\begin{tabular}{|c|c|c|c|c|}
\hline Log demand for apprentices $\Delta d_{s t, t-1}$ & Model 1 & Model 2 & Model 3 & Model 4 \\
\hline$\Delta \overline{B C}_{Q 2 t, t-1}$ & $\begin{array}{l}0.00318 * * * \\
(0.000389)\end{array}$ & $\begin{array}{l}0.00322^{* * *} \\
(0.000418)\end{array}$ & $\begin{array}{l}0.00371^{* * *} \\
(0.000455)\end{array}$ & \\
\hline$\Delta \overline{B C I}_{Q 2 t-1, t-2}$ & & & $\begin{array}{c}0.00295^{* * *} \\
(0.000633)\end{array}$ & \\
\hline$\Delta \bar{E}_{Q 2 t, t-1}$ & & & & $\begin{array}{c}0.00588^{* * *} \\
(0.000712)\end{array}$ \\
\hline$\Delta \bar{E}_{Q 2 t-1, t-2}$ & & & & $\begin{array}{c}0.00393^{* * *} \\
(0.000901)\end{array}$ \\
\hline$\Delta \log$ number of school graduates $g_{s t, t-1}$ & & $\begin{array}{c}0.135^{* * * *} \\
(0.0422)\end{array}$ & $\begin{array}{l}0.111 * * \\
(0.0381)\end{array}$ & $\begin{array}{l}0.115^{* *} \\
(0.0382)\end{array}$ \\
\hline$\Delta \log$ number of school graduates $g_{s t-1, t-2}$ & & & $\begin{array}{c}0.0963 * * \\
(0.0388)\end{array}$ & $\begin{array}{c}0.0949 * * \\
(0.0385)\end{array}$ \\
\hline Constant & $\begin{array}{c}0.00176 \\
(0.00464)\end{array}$ & $\begin{array}{c}0.00440 \\
(0.00386)\end{array}$ & $\begin{array}{c}0.00475 \\
(0.00373) \\
\end{array}$ & $\begin{array}{c}0.00293 \\
(0.00382)\end{array}$ \\
\hline $\begin{array}{l}\text { Observations } \\
\text { R-Squared }\end{array}$ & $\begin{array}{c}192 \\
0.136\end{array}$ & $\begin{array}{c}192 \\
0.193\end{array}$ & $\begin{array}{c}192 \\
0.332\end{array}$ & $\begin{array}{c}192 \\
0.342\end{array}$ \\
\hline
\end{tabular}

Notes: Heteroskedasticity and autocorrelation-robust standard errors in parentheses. $* * *$ Significant at the $1 \%$ level; ** significant at the $5 \%$-level; * significant at the $10 \%$-level. Data sources: Vocational training statistics of the statistical offices of the federal and state governments; ifo Business Climate Index and ifo Employment Barometer.

Thus, according to our model, changes in the BCI from 2007 to 2009 were associated with a $\frac{\partial \mathrm{d}}{\partial \mathrm{BIC}}=(-14) * 0.00371+(-4.3) * 0.00295=-0.065($ or $-6.5 \%)$ decrease $\quad$ in $\quad$ the demand for apprentices. Taking into account the most recent changes in BCI between 2019 and 2020, our model predicts that firm demand for apprentices will decrease by 
$\frac{\partial \mathrm{d}}{\partial \mathrm{BIC}}=(-21.7) * 0.00371+(-4) * 0.00295=-.0923, \quad$ or $-9.23 \% .{ }^{14} \quad$ Using $\quad$ the coefficients based on the ifo Employment Barometer, we find almost identical results, as $\frac{\partial \mathrm{d}}{\partial \mathrm{EB}}=(-13.3) * 0.00588+(-3.4) * 0.00393=-.0916$, or $-9.16 \%$.

\section{Unfilled vacancies, unsuccessful applicants, and business cycle expectations}

In competitive markets, we expect that we do not observe unfilled vacancies or unsuccessful applicants, as prices (which is mainly the apprentice wage in the context of apprenticeship training) would adjust and the market would eventually reach a new equilibrium after an unexpected macroeconomic shock (such as the financial crisis, or the current coronavirus pandemic). However, as already illustrated in Figure 6, there are considerable frictions in the German apprenticeship market that led to 53,000 unfilled vacancies in 2019 as well as almost 25,000 unsuccessful applicants.

Regressing unfilled vacancies on BCI at the state-level, we find a strong and positive effect. A 1-point increase in the BCI was associated with a $1.02 \%$ increase in unfilled vacancies. Moreover, when accounting for lagged effects, we find that a 1-point increase in the BCI in two consecutive years was associated with a $2.18 \%$ increase in unfilled vacancies (Models 1-3, Table 3). Conversely, we find no statistically significant association with changes in the BCI and changes in the number of unsuccessful applicants (Models 4-6, Table 3). ${ }^{15}$

\footnotetext{
${ }^{14}$ Our prediction is very close to currently observed changes in the demand for apprentices compared to the previous year, which decreased by $9.1 \%$ (apprenticeship market statistics May 2020; Federal Employment Agency, 2020b).

${ }^{15}$ We also ran the same regressions using EB rather than BCI as independent variables. The results are very similar and not included for reasons of brevity. The results are available from the authors upon request.
} 
Table 3: First-differences regression, unfilled vacancies and unsuccessful applicants (state-level, 20072019)

\begin{tabular}{lcccccc}
\hline Dependent variable: & \multicolumn{2}{c}{ Log unfilled vacancies $\Delta v_{s t, t-1}$} & \multicolumn{2}{c}{ Log unsuccessful applicants $\Delta u_{s t, t-1}$} \\
& Model 1 & Model 2 & Model 3 & Model 4 & Model 5 & Model 6 \\
\hline$\Delta \overline{B C I}_{Q 2 t, t-1}$ & $0.00876^{* *}$ & $0.00868^{* *}$ & $0.0102^{* * *}$ & -0.00217 & -0.00193 & -0.00206 \\
& $(0.00302)$ & $(0.00308)$ & $(0.00308)$ & $(0.00562)$ & $(0.00559)$ & $(0.00587)$ \\
$\Delta \overline{B C I}_{Q 2 t-1, t-2}$ & & & $0.0116^{* * *}$ & & & 0.000764 \\
& & & $(0.00338)$ & & & $(0.00452)$ \\
$\Delta$ log number of school & & -0.247 & -0.338 & & $0.699^{* *}$ & $0.695^{*}$ \\
graduates $g_{s t, t-1}$ & & $(0.277)$ & $(0.248)$ & & $(0.304)$ & $(0.344)$ \\
& & & & & & -0.362 \\
graduates $g_{s t-1, t-2}$ & & & -0.170 & & & $(0.367)$ \\
& & & $(0.168)$ & & -0.0137 & -0.0206 \\
Constant & $0.0888^{* * *}$ & $0.0840^{* * *}$ & $0.0755^{* * *}$ & $-0.0274^{* *}$ & & $(0.0119)$ \\
\hline Observations & $(0.0103)$ & $(0.0106)$ & $(0.0101)$ & $(0.0105)$ & $(0.0114)$ & 192 \\
R-Squared & 192 & 192 & 192 & 192 & 192 & 0.037 \\
\hline Nof & 0.034 & 0.040 & 0.099 & 0.001 & 0.029 & \\
\hline
\end{tabular}

Notes: Heteroskedasticity and autocorrelation-robust standard errors in parentheses. *** Significant at the 1\%level; ** significant at the $5 \%$-level; * significant at the $10 \%$ level. Data sources: Vocational training statistics of the statistical offices of the federal and state governments, ifo Business Climate Index and ifo Employment Barometer.

\section{Apprenticeship contracts and business cycle expectations}

Based on the previous results, we find that changes in BCI or EB are positively associated with firm demand for apprentices but are not associated with an increase in unsuccessful applicants for apprenticeship positions. We now turn to first estimating the association between $\mathrm{BCI} / \mathrm{EB}$ and the number of apprenticeship contracts at the state-level, and subsequently at the occupation-state-level in order to account for occupation-specific heterogeneity and developments. ${ }^{16}$

The results in Table 4 show the positive association between $\mathrm{BCI} / \mathrm{EB}$ and the number of signed state-level apprenticeship contracts, although the coefficients for $\Delta \overline{B C I}_{Q 2 t, t-1}$ and $\Delta \overline{E B}_{Q 2 t, t-1}$ are somewhat lower than our estimates for labor demand (Table 2), and substantially lower

\footnotetext{
${ }^{16}$ Data at the occupation-level within states are only available until the end of 2018.
} 
compared to the regressions of unfilled vacancies (Table 3). Thus, our results suggest that business climate changes were not fully absorbed in the German apprenticeship market, instead resulting in an increasing number of unfilled vacancies in recent years (when $\Delta \overline{B C I}_{Q 2 t, t-1}>0$ ). Our observation, that the number of unsuccessful applicants did not decrease substantially in recent years, can be explained i) by matching problems and ii) by the fact that many individuals, who are originally interested in apprenticeship training, do not end up being counted as unsuccessful applicants. Instead, labor market or schooling alternatives to apprenticeship training fill the void created by unsuccessful applications. ${ }^{17}$

Table 4: First-differences regression, new annual apprenticeship contracts (state-level, 2007-2019) Dep.variable: log apprenticeship contracts

\begin{tabular}{|c|c|c|c|c|}
\hline$\Delta a_{s t, t-1}$ & Model 1 & Model 2 & Model 3 & Model 4 \\
\hline$\Delta \overline{B C I}_{Q 2 t, t-1}$ & $0.00281 * * *$ & $0.00285 * * *$ & $0.00327 * * *$ & \\
\hline & $(0.000405)$ & $(0.000451)$ & $(0.000490)$ & \\
\hline$\Delta \overline{B C I}_{Q 2 t-1, t-2}$ & & & $\begin{array}{c}0.00243 * * * \\
(0.000701)\end{array}$ & \\
\hline$\Delta \bar{E}_{Q 2 t, t-1}$ & & & & $\begin{array}{c}0.00507 * * * \\
(0.000760)\end{array}$ \\
\hline$\Delta \bar{E}_{Q 2 t-1, t-2}$ & & & & $\begin{array}{c}0.00332 * * * \\
(0.00100)\end{array}$ \\
\hline$\Delta \log$ number of school graduates $g_{s t, t-1}$ & & $\begin{array}{c}0.139 * * * \\
(0.0466)\end{array}$ & $\begin{array}{l}0.119^{* *} \\
(0.0411)\end{array}$ & $\begin{array}{l}0.122 * * \\
(0.0415)\end{array}$ \\
\hline$\Delta \log$ number of school graduates & & & $0.106^{* *}$ & $0.104 * *$ \\
\hline$g_{s t-1, t-2}$ & & & $(0.0390)$ & $(0.0387)$ \\
\hline Constant & $\begin{array}{c}-0.00308 \\
(0.00508)\end{array}$ & $\begin{array}{r}-0.000355 \\
(0.00415)\end{array}$ & $\begin{array}{l}0.000408 \\
(0.00391)\end{array}$ & $\begin{array}{l}-0.00119 \\
(0.00402)\end{array}$ \\
\hline Observations & 192 & 192 & 192 & 192 \\
\hline R-squared & 0.095 & 0.149 & 0.248 & 0.253 \\
\hline
\end{tabular}

Notes: Heteroskedasticity and autocorrelation-robust standard errors in parentheses. $* * *$ Significant at the $1 \%$ level; ** significant at the $5 \%$-level; * significant at the $10 \%$ level. Data sources: Vocational training statistics of the statistical offices of the federal and state governments, ifo Business Climate Index and ifo Employment Barometer.

However, the number of observations at the state-level is relatively small and we are not able to account for occupation-specific heterogeneity by using only aggregate statistics. For that

\footnotetext{
${ }^{17}$ We also ran similar regressions of the number of unsuccessful applicants that had already found an alternative (as published by the Federal Employment Agency) on the BCI for the period of 2007-2019, but found no evidence for a statistically significant association.
} 
reason, we make use of more fine-grained data at the occupation-state-level (vocational training statistics of the statistical offices of the federal and state governments). Regression results are presented in Table 5.

In order to estimate the effect of the financial crisis, which started to affect BCI and EB in the fall of 2008, we estimate $\Delta a_{o s 2009,2008}=\beta_{1} * \Delta \overline{B C I}_{Q 2 t, Q 2 t-1}+\beta_{2} * \Delta \overline{B C I}_{Q 2 t, Q 2 t-1}$, which is the change in the number of apprenticeship contracts due to changes in the $\mathrm{BCI}$ in the particular period (applied correspondingly for EB). According to our analysis (Model 5, Table 5), the drop in the Business Climate Index from 2008 to 2009 (which was -14 index points, cf. Table 1) was therefore associated with a $0.00279 *(-14.0)=-3.9 \%$ decrease in the number of apprenticeship positions. However, as the index already dropped from the second quarter in 2007 to the second quarter 2008 by 4.3 index points, this caused an additional decrease in apprenticeship contracts of $0.00187 *(-4.3)=-0.8 \%$. In sum, changes in the BCI between 2007 and 2009 are therefore associated with a $4.7 \%$ decrease in the number of apprenticeship contracts (ceteris paribus). Our estimation using EB as the key indicator for expected business cycle changes yielded larger coefficients, but as the Employment Barometer seems somewhat less sensitive to economic developments (leading to a smaller decline, relative to the $\mathrm{BCI}$ ), total results are very similar $(4.9 \% \text { decrease })^{18}$. As the overall decrease in the number of new apprenticeships from 2008 to 2009 was $7.7 \%$ (cf. BIBB, 2019), changes in the BCI can explain $61 \%$ of that decrease in the number of apprenticeship contracts. Clearly, demographic change was a second relevant influencing factor that can, in part, explain the decrease in apprenticeships in Germany since 2008.

\footnotetext{
${ }^{18}$ Changes in the Employment Barometer (EB) amount to (-1.4) from 2007 to 2008, and (-9.9) from 2008 to 2009 (Table 1). Thus, based on the coefficients in Model 6 (Table 5), changes in the EB suggest a $4.86 \%$ decrease in the number of apprenticeship contracts from 2008 to 2009.
} 
Table 5: First-differences regression (occupation-state-level, 2007-2018)

\begin{tabular}{|c|c|c|c|c|c|c|}
\hline $\begin{array}{l}\text { Dependent variable: log } \\
\text { number of apprenticeship } \\
\text { contracts } \Delta a_{o s t, t-1}\end{array}$ & Model 1 & Model 2 & Model 3 & Model 4 & Model 5 & Model 6 \\
\hline$\Delta \overline{B C I}_{Q 2 t, t-1}$ & $0.00211^{* * *}$ & $0.00215 * * *$ & $0.00284 * * *$ & $0.00280 * * *$ & $0.00279 * * *$ & \\
\hline & $(0.000429)$ & $(0.000457)$ & $(0.000457)$ & $(0.000459)$ & $(0.000459)$ & \\
\hline$\Delta \overline{B C I}_{Q 2 t-1, t-2}$ & & & $\begin{array}{l}0.00201 * * * \\
(0.000385)\end{array}$ & $\begin{array}{r}0.00186^{* * *} \\
(0.000388)\end{array}$ & $\begin{array}{r}0.00187^{* * *} \\
(0.000388)\end{array}$ & \\
\hline$\Delta \overline{E B}_{Q 2 t, t-1}$ & & & & & & $\begin{array}{r}0.00457^{* * *} \\
(0.000650)\end{array}$ \\
\hline$\Delta \overline{E B}_{Q 2 t-1, t-2}$ & & & & & & $\begin{array}{l}0.00245^{* * *} \\
(0.000576)\end{array}$ \\
\hline $\begin{array}{l}\Delta \text { log number of school } \\
\text { graduates } g_{s t, t-1}\end{array}$ & & $0.215^{* * *}$ & $0.211 * * *$ & $0.200 * * *$ & $0.191 * * *$ & $0.194 * * *$ \\
\hline & & $(0.0230)$ & $(0.0251)$ & $(0.0252)$ & $(0.0251)$ & $(0.0251)$ \\
\hline $\begin{array}{l}\Delta \text { log number of school } \\
\text { graduates } g_{s t-1, t-2}\end{array}$ & & & $\begin{array}{c}0.0908^{* * *} \\
(0.0246)\end{array}$ & $\begin{array}{c}0.0742^{* * *} \\
(0.0247)\end{array}$ & $\begin{array}{c}0.0528^{* * *} \\
(0.0250)\end{array}$ & $\begin{array}{c}0.0568 * * * \\
(0.0250)\end{array}$ \\
\hline Trend*East Germany & & & & & $\begin{array}{l}-0.00233^{* * *} \\
(0.000411)\end{array}$ & $\begin{array}{c}-0.00273 * * * \\
(0.000272)\end{array}$ \\
\hline Occupation-level trends & No & No & No & Yes & Yes & Yes \\
\hline Constant & $\begin{array}{c}-0.0250^{* * *} \\
(0.00145) \\
\end{array}$ & $\begin{array}{c}-0.0208^{* * *} \\
(0.00147) \\
\end{array}$ & $\begin{array}{c}-0.0244 * * * \\
(0.00159) \\
\end{array}$ & $\begin{array}{c}-0.118^{* * *} \\
(0.0450) \\
\end{array}$ & $\begin{array}{l}-0.114 * * \\
(0.0450) \\
\end{array}$ & $\begin{array}{l}-0.114 * * \\
(0.0477) \\
\end{array}$ \\
\hline Observations & 38880 & 38880 & 34160 & 34160 & 34160 & 34160 \\
\hline R-squared & 0.001 & 0.003 & 0.005 & 0.028 & 0.028 & 0.029 \\
\hline
\end{tabular}

Notes: Heteroskedasticity and autocorrelation-robust standard errors in parentheses. $* * *$ Significant at the 1\%level; ** significant at the $5 \%$-level; * significant at the $10 \%$ level. Data sources: Vocational training statistics of the statistical offices of the federal and state governments, ifo Business Climate Index (BCI), ifo Employment Barometer (EB)

Our analysis further shows that apprentices with a high school degree (and, to a lesser extent, individuals with a lower-level school degree, i.e., Hauptschule) are more strongly affected by changes in the business cycle (cf. Tables A4-A6; offering additional evidence for suggestions by Maier, 2020). By contrast, apprenticeship contracts with individuals that have obtained midlevel school degrees (Realschule) seem to remain largely unaffected by changes in the business climate from 2007-2018. We propose that this is primarily driven by principal differences in the availability of labor market or schooling alternatives (to apprenticeships) that are open to the respective educational segment. As prospects for available apprenticeship positions worsen in an economic downturn, high school graduates may increasingly opt for alternative career paths, such as university programs. By contrast, low-level school graduates are expected not to 
evade negative effects of crises, but instead to suffer from them directly. Two primary mechanisms are conceivable. Firstly, as competition for available apprenticeships tightens, other applicants with higher-level schooling degrees may increasingly fill positions with usually less demanding schooling requirements. Secondly, firms that, during "normal" times, represent the primary employers for applicants with low-level schooling qualifications may be exposed to higher amounts of economic risks and financial strain during times of crisis, causing them to reduce their apprenticeship offering disproportionately, or drop out of the market altogether. Mid-level school graduates, on the other hand, seem to be able to potentially benefit from these movements in the other two educational segments, leaving them less exposed to business cycle developments.

\section{What is the predicted effect of Covid-19 on the German apprenticeship market?}

Figure 7 plots the predicted change in the log number of apprenticeship contracts due to changes in the BCI from 2007 to 2018 and adds out-of-sample predictions for the years 2019 and $2020^{19}$. The average level of the second quarter BCI in 2019 was 98.6 , while the index fell to 74.3 in April, and then slightly increased to 79.5 in May 2020. Therefore, to the extent that we can extrapolate our findings from the 2007-2018 period (i.e., our estimates for coefficients of $\Delta \overline{B C I}_{Q 2 t, t-1}$ and $\Delta \overline{B C I}_{Q 2 t-1, t-2}$ in Table 5, Model 5), we would expect a decline in the number of apprenticeship contracts in 2020 of $\Delta a_{o s 2020,2019}=\beta * \Delta \overline{B C I}_{Q 22020, Q 22019}+\beta *$ $\Delta \overline{B C I}_{Q 22019, Q 22018}=0.00279 *(-21.7)+0.00187 *(-4) \cong-0.068,(\mathrm{CI}:+/-0.0173) .{ }^{20}$ This corresponds, on average, to approximately 34,700 (95\% CI: +/- 8,800) fewer vocational

\footnotetext{
${ }^{19}$ The state- and occupation-level number of apprenticeship contracts are not yet available for 2019, even though an estimate of the total number of apprenticeship positions in 2019 (510,710 firm-sponsored apprenticeships) has already been published (Berufsbildungsbericht 2019; BIBB, 2019).

${ }^{20}$ The corresponding estimate based on the coefficients of the ifo Employment Barometer (EB) in Model 6

(Table 5) is almost identical, as $(-3.4) * 0.00245+(-13.3) * 0.00457=-0.069$.
} 
training positions compared to 2019, largely due to the recent Covid-19-induced change in expectations about the business climate ${ }^{21}$.

Figure 7: Marginal effects of the BCI (ceteris paribus) on the number of new apprenticeships (20072018) and predicted effects for the years 2019 and 2020

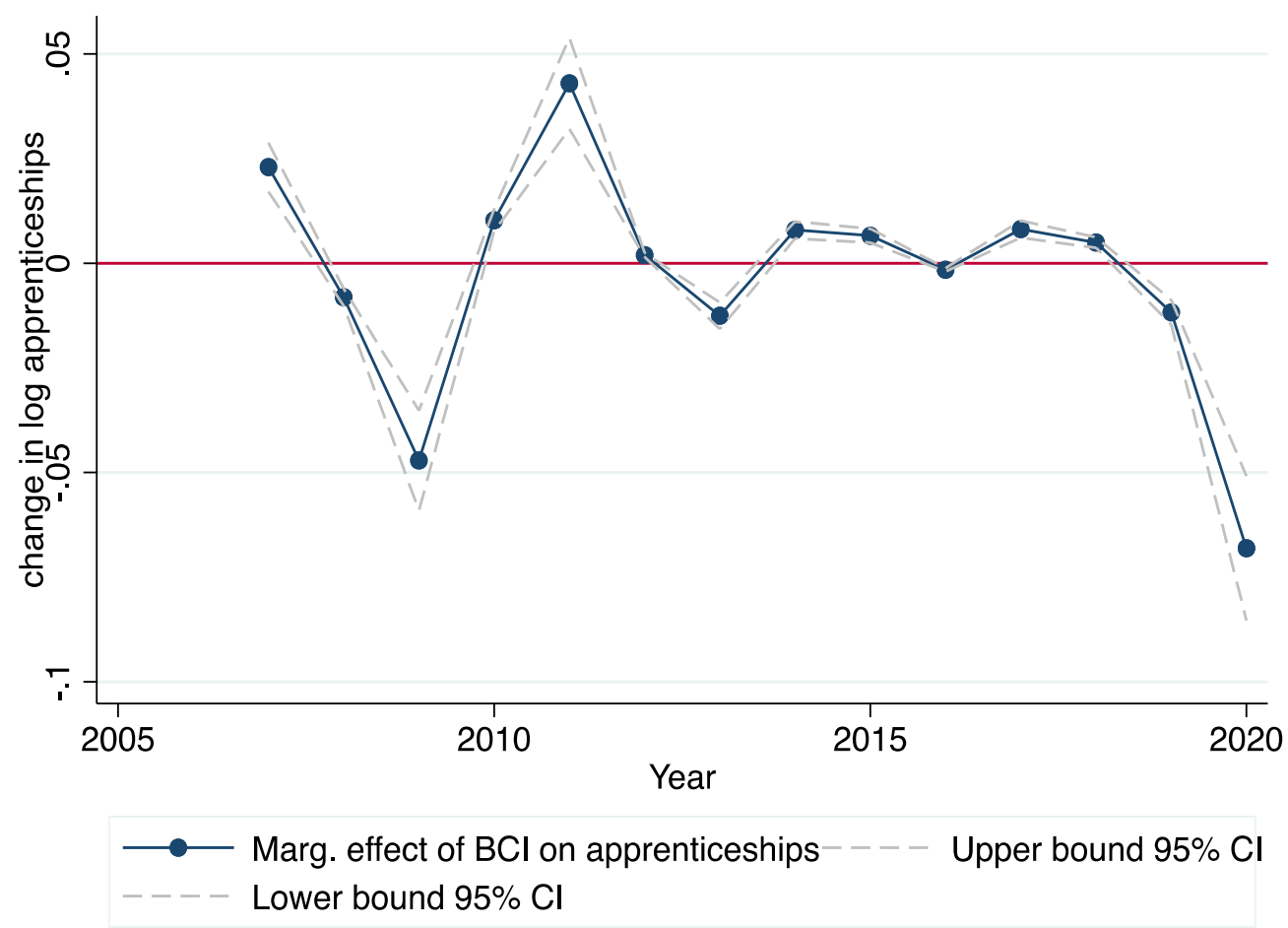

Notes: Blue line indicates to what extent changes in the ifo BCI (average value of the second quarter of each year) affect the annual number of new apprenticeship contracts signed by the end of the same year. Out-of-sample forecasts for the years 2019 and 2020 that include current ifo BCI data for January 2019 - May 2020. Data sources: Vocational training statistics of the statistical offices of the federal and state governments, ifo Business Climate Index.

\footnotetext{
${ }^{21} \mathrm{~A}$ further effect of changes in business cycle expectations could be an increase in the premature termination rate of apprenticeship contracts. Our state-level estimates in Table A3, however, show no evidence that changes in the BCI had a statistically significant association with changes in the rate of premature apprenticeship contract terminations in the years 2007-2018.
} 


\section{Conclusions}

Empirical evidence for Germany shows that the apprenticeship market is susceptible to business cycle fluctuations. Thus, the large and unexpected economic shock associated with the Covid19 pandemic and the lockdown measures that came in its wake are likely to affect the German apprenticeship market in 2020. Based on our analysis of the association between two indicators of business cycle expectations (the ifo Business Climate Index and the ifo Employment Barometer) and subsequent apprenticeship contracts from 2007 to 2018, which also includes the financial crisis in $2008 / 2009$, we predict that current company expectations about business cycle developments will lead to a reduction in the number of apprenticeship contracts in August/September 2020 by $6.8 \%$ or 34,700 positions (95\% CI: $+/-8,800)$. Moreover, our results suggest that the effect of the crisis will be more pronounced for the demand for apprentices (i.e., the sum of apprenticeship contracts and unfilled vacancies), where our regression model predicts a 9.1\% decrease based on German firms' current business cycle expectations (as measured through the BCI). This is driven by frictions in the apprenticeship market. In 2019, the total demand for apprentices exceeded the total supply and resulted in 53,000 unfilled vacancies. Therefore, the effect of Covid-19 on the number of apprenticeship contracts will likely be less severe than if we had had a situation of excess supply prior to the start of the current crisis, as was the case in 2008 (before the start of the financial crisis). In a number of occupations and regions in 2020, many firms would simply not have been able to successfully fill their vacancies in the absence of the coronavirus crisis, in part because demographic changes continue to put downward pressure on the number of school leavers. Furthermore, we did not find any statistically significant association between changes in the $\mathrm{BCI} / \mathrm{EB}$ and changes in the number of unsuccessful applicants in the period between 2007 and 2019. Thus, there is some hope that the number of unsuccessful applicants in the apprenticeship market will not increase as drastically in occupations where demand exceeded supply in 2019. Nonetheless, there will likely be a strong increase in the number of individuals that have to accept alternative 
educational arrangements, such as preparatory courses to increase the chances to secure an apprenticeship position in 2021 (and thus compete for apprenticeship positions with next year's school leavers). Our analysis shows that this will apply especially to school graduates with lower school attainment (Hauptschule), because those with a high-school degree (Abitur) will have other options available to them, for example, to pursue a tertiary degree.

A cautionary note appears appropriate for all our forward-looking results. While our econometric model offers predictions based on historic market information, it cannot provide definitive answers for how the crisis and associated consequences for apprenticeships will unfold. We do, however, provide initial means to estimate and thus prepare for the likely impact of Covid-19 on the German apprenticeship market. Furthermore, the benefit of our approach is that the analysis can easily be updated once more data become available. Our predictions remain a "best guess" estimate, based on the information available at the time.

Finally, the current pandemic and the resulting economic downturn coincide with significant regulatory changes that have introduced a minimum wage for German apprentices at the beginning of 2020. Initial studies on the likely impact of the specific level of the German minimum wage for apprentices suggest that it is largely small companies and those in the eastern German states that would see rising costs (Wenzelmann \& Pfeifer, 2018). These influences may be felt in addition to the expected effects we have described and while we do not discuss them in greater detail, they should provide ample material for future research efforts. 


\section{References}

Acemoglu, D., \& Pischke, J.-S. (1999). The structure of wages and investment in general training. Journal of Political Economy, 107(3), 539-572.

Askilden, J. E., \& Nilsen, Ø. A. (2005). Apprentices and yound workers: A study of the Norwegian youth labour market. Scottish Journal of Political Economy, 52(1), 1-17.

Azubiyo GmbH. (2020). Bewerbungsfristen im Überblick. Retrieved from https://www.azubiyo.de/bewerbung/bewerbungsfrist-ausbildung/

Baldi, G., Brüggemann-Borck, I., \& Schlaak, T. (2014). The effect of the business cycle on apprenticeship training: Evidence from Germany. Munich Personal RePEc Archive Paper, 59116, 1-15.

Becker, G. S. (1964). Human capital: A theoretical and empirical analysis, with special references to education. In. New York: Columbia University Press.

Beckmann, M. (2002). Firm-sponsored apprenticeship training in Germany: Empirical evidence from establishment data. Review of Labour Economics and Industrial Relations, 16(2), 287-310.

Bell, D. N. F., \& Blanchflower, D. G. (2011). Young people and the Great Recession. Oxford Review of Economic Policy, 27(2), 241-267.

Bellmann, L., Gerner, H.-D., \& Leber, U. (2014). Firm-provided training during the Great Recession. Jahrbücher für Nationalökonomie und Statistik, 234(1), 5-22.

Brunello, G. (2009). The effect of economic downturns on apprenticeships and initial workplace training: A review of the evidence. Empirical Research in Vocational Education and Training, 1(2), 145-171.

Bundesinstitut für Berufsbildung (BIBB). (2019). Datenreport zum Berufsbildungsbericht 2019. Bonn: BIBB.

Bundesministerium für Bildung und Forschung (BMBF). (2018). Ausbildung \& Beruf: Rechte und Pflichten während der Berufsausbildung. Retrieved from https://www.bmbf.de/upload_filestore/pub/Ausbildung_und_Beruf.pdf

Bundesministerium für Bildung und Forschung (BMBF). (2019). Entwurf eines Gesetzes zur Modernisierung und Stärkung der beruflichen Bildung. Retrieved from https://www.bmbf.de/files/Gesetzentwuf_Bundesregierung_BBiG_Novelle_final.pdf

Destatis. (2012). Berufsbildungsstatistik - Begriffe und Erläuterungen (H204/32120990). Wiesbaden: Statistisches Bundesamt.

Dietrich, H., \& Gerner, H.-D. (2007). The determinants of apprenticeship training with particular reference to business expectations. Zeitschrift für Arbeitsmarktforschung, 40(2/3), 221-233.

Dionisius, R., Mühlemann, S., Pfeifer, H., Walden, G., Wenzelmann, F., \& Wolter, S. C. (2009). Cost and benefits of apprenticeship training: A comparison of Germany and Switzerland. Applied Economics Quarterly, 55(1), 7-37.

Dustmann, C., \& Schönberg, U. (2009). Training and union wages. The Review of Economics and Statistics, 91(2), 363-376.

Dustmann, C., \& Schönberg, U. (2012). What makes firm-based vocational training schemes successful? The role of commitment. American Economic Journal: Applied Economics, 4(2), 36-61.

European Commission. (2012). Apprenticehsip supply in the member states of the European Union: Final report. Luxembourg: Publications Office of the European Union.

Federal Employment Agency. (2020a). Arbeitslose und Arbeitslosenquoten - Deutschland und West/Ost (Zeitreihe Monats- und Jahreszahlen ab 1950).

Federal Employment Agency. (2020b). Ausbildungsstellenmarkt. Retrieved from https://statistik.arbeitsagentur.de/Navigation/Statistik/Statistik-nachThemen/Ausbildungsstellenmarkt/zu-den-Daten/zu-den-Daten-Nav.html 
Federal Labour Court. (1987). Kündigung nach $§ 15$ Abs. 1 BBiG vor Beginn der Ausbildung - Urteil vom 17. September 1987. 2 AZR 654/86.

Harhoff, D., \& Kane, T. J. (1997). Is the German apprenticeship system a Panacea for the U.S. labor market? Journal of Population Economics, 10(2), 171-196.

Hashimoto, M. (1982). Minimum wage effects on training on the job. The American Economic Review, 72(5), 1080-1087.

Hippach-Schneider, U., \& Huismann, A. (2016). Germany - VET in Europa - 2016 Country Report. Bonn: Bundesinstitut für Berufsbildung (BIBB).

Kriechel, B., Mühlemann, S., Pfeifer, H., \& Schütte, M. (2014). Works councils, collective bargaining, and apprenticeship training: Evidence from German firms. Industrial Relations, 53(2), 199-222.

Leighton, L., \& Mincer, J. (1981). The effects of minimum wages on human capital formation. In S. Rottenberg (Ed.), The economics of legal minimum wages (pp. 155173). Washington, DC: American Enterprise Institute for Public Policy Research.

Lindley, R. M. (1975). The demand for apprentice recruits by the engineering industry, 195171. Scottish Journal of Political Economy, 22(1), 1-24.

Lüthi, S., \& Wolter, S. C. (2020a). Are apprenticeships business cycle proof. Swiss Journal of Economics and Statistics, 156(3), 1-11.

Lüthi, S., \& Wolter, S. C. (2020b). The impact of the COVID-19 crisis on the provision of apprenticeships in Switzerland. Leading House Short Note, May 8, 2020, 1-4.

Maier, T. (2020). Auswirkungen der "Corona-Krise" auf die duale Berufsausbildung: Risiken, Konsequenzen und Handkungsnotwendigkeiten. Bonn: Bundesinstitut für Berufsbildung.

Merrilees, W. J. (1983). Alternative models of apprentice recruitment: With special reference to the British engineering industry. Applied Economics, 15(1), 1-21.

Mühlemann, S., Pfeifer, H., Walden, G., Wenzelmann, F., \& Wolter, S. C. (2010). The financing of apprenticeship training in the light of labor market regulations. Labour Economics, 17, 799-809.

Mühlemann, S., Wolter, S. C., \& Wüest, A. (2009). Apprenticeship training and the business cycle. Empirical Research in Vocational Education and Training, 2, 173-186.

Rohrbach-Schmidt, D., \& Uhly, A. (2016). Datenschatz Berufsbildungsstatistik Nutzungsmöglichkeiten für die Forschung. Berufsbildung in Wissenschaft und Praxis, 45(2), 40-44.

Sauer, S., \& Wohlrabe, K. (2020). ifo Handbuch der Konjunkturumfrage. ifo Beiträge zur Wirtschaftsforschung, 88, 1-362.

Schönfeld, G., Jansen, A., Wenzelmann, F., \& Pfeifer, H. (2016). Kosten und Nutzen der dualen Ausbildung aus Sicht der Betriebe: Ergebnisse der fünften BIBB-KostenNutzen-Erhebung. Bonn: Bundesinstitut für Berufsbildung.

Schweri, J., \& Müller, B. (2008). Die Ausbildungsbereitschaft der Betriebe: Entwicklungen 1995 bis 2005. Bundesamt für Statistik, 18(1), 359-375.

Stevens, M. (1994). An investment model for the supply of training by employers. The Economic Journal, 104(424), 556-570.

U.S. Bureau of Labor Statistics (USBLS). (2020a). Economic news release: Employment situation summary. Retrieved from https://www.bls.gov/news.release/empsit.nr0.htm

U.S. Bureau of Labor Statistics (USBLS). (2020b). Labor force statistics from the current population survey. Retrieved from https://www.bls.gov/web/empsit/cpseea03.htm

Wenzelmann, F., \& Pfeifer, H. (2018). Die Mindestausbildungsvergütung aus betrieblicher Perspektive: Einschätzungen auf Basis von datenbasierten Simulationen. BIBB Report, 4/2018, 1-12. 
Weßling, K., Hartung, A., \& Hillmert, S. (2015). Spatial structure counts: The relevance of regional labour-market conditions for educational transitions to vocational training. Empirical Research in Vocational Education and Training, 7(12), 1-20.

Westergaard-Nielsen, N., \& Rasmussen, A. R. (1999). The impact of subsidies on the number of new apprentices. Research in Labor Economics, 18(1), 359-375.

Wohlrabe, K. (2018). Das neue ifo Beschäftigungsbarometer. ifo Schnelldienst, 71(9), 34-36.

Wolter, S. C., \& Ryan, P. (2011). Apprenticeship. In E. A. Hanushek, S. Machin, \& L. Woessmann (Eds.), Handbook of the Economics of Education (Vol. 3, pp. 521-576). Amsterdam: North-Holland. 
Table A1: Number of new apprenticeships by occupation (2007-2012)

\begin{tabular}{|c|c|c|c|c|c|c|c|c|c|c|c|c|}
\hline \multirow[b]{3}{*}{ State } & \multicolumn{12}{|c|}{ Number of apprenticeships by occupation } \\
\hline & \multicolumn{2}{|c|}{2007} & \multicolumn{2}{|c|}{2008} & \multicolumn{2}{|c|}{2009} & \multicolumn{2}{|c|}{2010} & \multicolumn{2}{|c|}{2011} & \multicolumn{2}{|c|}{2012} \\
\hline & Mean & SD & Mean & SD & Mean & SD & Mean & SD & Mean & SD & Mean & SD \\
\hline Schleswig-Holstein & 94 & 193 & 92 & 189 & 90 & 181 & 86 & 182 & 87 & 180 & 86 & 178 \\
\hline Hamburg & 68 & 134 & 68 & 135 & 63 & 124 & 67 & 134 & 63 & 131 & 63 & 127 \\
\hline Lower Saxony & 226 & 481 & 219 & 476 & 209 & 453 & 215 & 472 & 227 & 499 & 216 & 470 \\
\hline Bremen & 32 & 58 & 32 & 58 & 31 & 54 & 32 & 55 & 31 & 56 & 32 & 58 \\
\hline North Rhine-Westphalia & 458 & 1075 & 436 & 991 & 412 & 957 & 426 & 1003 & 429 & 1017 & 420 & 996 \\
\hline Hesse & 162 & 383 & 155 & 362 & 147 & 348 & 144 & 344 & 147 & 344 & 148 & 340 \\
\hline Rhineland-Palatinate & 125 & 277 & 117 & 254 & 113 & 249 & 114 & 249 & 111 & 247 & 110 & 239 \\
\hline Baden-Württemberg & 284 & 641 & 280 & 639 & 269 & 610 & 264 & 606 & 277 & 634 & 265 & 622 \\
\hline Bavaria & 359 & 836 & 356 & 841 & 322 & 760 & 326 & 779 & 332 & 795 & 333 & 774 \\
\hline Saarland & 47 & 90 & 45 & 85 & 45 & 85 & 43 & 80 & 44 & 78 & 43 & 80 \\
\hline Berlin & 100 & 231 & 89 & 207 & 86 & 194 & 83 & 187 & 79 & 175 & 81 & 178 \\
\hline $\begin{array}{l}\text { Brandenburg } \\
\text { Mecklenburg- }\end{array}$ & 77 & 166 & 69 & 145 & 60 & 127 & 56 & 117 & 49 & 101 & 46 & 94 \\
\hline Vorpommern & 76 & 164 & 65 & 132 & 51 & 101 & 47 & 90 & 42 & 78 & 41 & 75 \\
\hline Saxony & 115 & 239 & 98 & 207 & 89 & 193 & 79 & 171 & 74 & 158 & 69 & 136 \\
\hline Saxony-Anhalt & 81 & 164 & 74 & 148 & 62 & 125 & 57 & 115 & 52 & 106 & 51 & 98 \\
\hline Thuringia & 73 & 142 & 66 & 129 & 56 & 108 & 51 & 100 & 46 & 88 & 46 & 85 \\
\hline
\end{tabular}

Data sources: Vocational training statistics of the statistical offices of the federal and state governments.

Table A2: Number of new apprenticeships by occupation (2013-2018)

\begin{tabular}{|c|c|c|c|c|c|c|c|c|c|c|c|c|}
\hline \multirow[b]{3}{*}{ State } & \multicolumn{12}{|c|}{ Number of apprenticeships by occupation } \\
\hline & \multicolumn{2}{|c|}{2013} & \multicolumn{2}{|c|}{2014} & \multicolumn{2}{|c|}{2015} & \multicolumn{2}{|c|}{2016} & \multicolumn{2}{|c|}{2017} & \multicolumn{2}{|c|}{2018} \\
\hline & Mean & SD & Mean & SD & Mean & SD & Mean & SD & Mean & SD & Mean & SD \\
\hline Schleswig-Holstein & 81 & 170 & 83 & 172 & 82 & 169 & 87 & 174 & 84 & 170 & 84 & 165 \\
\hline Hamburg & 61 & 124 & 61 & 123 & 62 & 126 & 62 & 123 & 61 & 120 & 62 & 120 \\
\hline Lower Saxony & 205 & 453 & 211 & 460 & 204 & 445 & 204 & 440 & 211 & 445 & 206 & 439 \\
\hline Bremen & 31 & 55 & 31 & 55 & 31 & 55 & 31 & 55 & 31 & 53 & 30 & 54 \\
\hline North Rhine-Westphalia & 415 & 981 & 402 & 948 & 401 & 943 & 400 & 927 & 408 & 933 & 408 & 928 \\
\hline Hesse & 140 & 317 & 140 & 312 & 138 & 308 & 135 & 301 & 141 & 303 & 141 & 308 \\
\hline Rhineland-Palatinate & 104 & 225 & 105 & 228 & 103 & 217 & 104 & 218 & 100 & 214 & 102 & 212 \\
\hline Baden-Württemberg & 259 & 598 & 258 & 592 & 264 & 597 & 262 & 588 & 267 & 591 & 271 & 593 \\
\hline Bavaria & 321 & 755 & 319 & 745 & 321 & 745 & 316 & 735 & 326 & 748 & 331 & 759 \\
\hline Saarland & 42 & 74 & 40 & 70 & 41 & 71 & 39 & 69 & 39 & 68 & 37 & 64 \\
\hline Berlin & 74 & 161 & 72 & 152 & 71 & 148 & 70 & 146 & 70 & 142 & 72 & 143 \\
\hline Brandenburg & 44 & 86 & 43 & 83 & 44 & 86 & 43 & 83 & 42 & 84 & 44 & 86 \\
\hline Mecklenburg-Vorpommern & 38 & 72 & 39 & 71 & 38 & 71 & 39 & 69 & 39 & 68 & 40 & 71 \\
\hline Saxony & 68 & 134 & 69 & 136 & 69 & 134 & 71 & 135 & 75 & 141 & 75 & 143 \\
\hline Saxony-Anhalt & 47 & 93 & 48 & 94 & 48 & 92 & 48 & 93 & 45 & 87 & 47 & 90 \\
\hline Thuringia & 44 & 82 & 43 & 80 & 45 & 80 & 44 & 78 & 45 & 81 & 46 & 83 \\
\hline
\end{tabular}

Data sources: Vocational training statistics of the statistical offices of the federal and state governments. 
Table A3: First-differences regression, prematurely terminated training contracts (state-level)

\begin{tabular}{lcc}
\hline Dependent variable $(\log ): \Delta t c_{s t, t-1}$ & Model 1 & Model 2 \\
\hline$\Delta \overline{B C I}_{Q 2 t, t-1}$ & -0.0000517 & 0.0000429 \\
& $(0.000381)$ & $(0.000373)$ \\
$\Delta \log$ number of school graduates $g_{s t, t-1}$ & & 0.00125 \\
& & $(0.0445)$ \\
Constant & 0.000373 & -0.00333 \\
& $(0.00535)$ & $(0.00599)$ \\
\hline Observations & 176 & 174 \\
R-squared & 0.148 & 0.428 \\
\hline Nos:
\end{tabular}

Notes: Heteroskedasticity and autocorrelation-robust standard errors in parentheses. $* * *$ Significant at the 1\%level; ** significant at the $5 \%$-level; * significant at the $10 \%$ level. Data sources: Vocational training statistics of the statistical offices of the federal and state governments, ifo Business Climate Index.

Table A4: First-differences regression (occupation-state-level, apprentices with a high school degree)

\begin{tabular}{lccccc}
\hline Dependent variable (log): $\Delta a_{\text {ost }, t-1}$ & Model 1 & Model 2 & Model 3 & Model 4 & Model 5 \\
\hline$\Delta \overline{B C I}_{Q 2 t, t-1}$ & $0.00196^{* * *}$ & $0.00247^{* * *}$ & $0.00273^{* * *}$ & $0.00267^{* * *}$ & $0.00257^{* *}$ \\
& $(0.000592)$ & $(0.000590)$ & $(0.000640)$ & $(0.000644)$ & $(0.000645)$ \\
$\Delta \log$ number of school graduates & & & & & \\
$g_{s t, t-1}$ & & $0.179^{* * *}$ & $0.178^{* * *}$ & $0.177^{* * *}$ & $0.160^{* * *}$ \\
& & $(0.0182)$ & $(0.0184)$ & $(0.0184)$ & $(0.0186)$ \\
$\Delta \overline{B C I}_{Q 2 t-1, t-2}$ & & & $0.00181^{* * *}$ & $0.00165^{* * *}$ & $0.00163^{* * *}$ \\
& & & $(0.000552)$ & $(0.000558)$ & $(0.000557)$ \\
$\Delta \log$ number of school graduates & & & & & \\
$g_{s t-1, t-2}$ & & & $0.0634^{* * *}$ & $0.0617^{* * *}$ & $0.0433^{* * *}$ \\
& & & $(0.0174)$ & $(0.0174)$ & $(0.0178)$ \\
Trend*East Germany & & & & & $-0.0527^{* *}$ \\
& No & No & No & Yes & Yes \\
Occupation-level trends & $0.0301^{* * *}$ & $0.0299^{* * *}$ & $0.0287^{* * *}$ & -0.0488 & -0.0366 \\
Constant & $(0.00197)$ & $(0.00195)$ & $(0.00215)$ & $(0.0343)$ & $(0.0391)$ \\
& 27367 & 27367 & 24669 & 24669 & 24669 \\
\hline Observations & 0.001 & 0.005 & 0.005 & 0.021 & 0.023 \\
R-squared & & & & \\
\hline
\end{tabular}

Notes: Heteroskedasticity and autocorrelation-robust standard errors in parentheses. $* * *$ Significant at the $1 \%$ level; ** significant at the 5\%-level; * significant at the $10 \%$ level. Data sources: Vocational training statistics of the statistical offices of the federal and state governments, ifo Business Climate Index. 
Table A5: First-differences regression (occupation-state-level, apprentices with a mid-level school degree)

\begin{tabular}{|c|c|c|c|c|c|}
\hline Dependent variable $(\log ): \Delta a_{o s t, t-1}$ & Model 1 & Model 2 & Model 3 & Model 4 & Model 5 \\
\hline$\Delta \overline{B C I}_{Q 2 t, t-1}$ & $\begin{array}{c}0.000842 \\
(0.000526)\end{array}$ & $\begin{array}{c}0.000830 \\
(0.000526)\end{array}$ & $\begin{array}{l}0.0000311 \\
(0.000565)\end{array}$ & $\begin{array}{c}-0.00000704 \\
(0.000568)\end{array}$ & $\begin{array}{l}0.0000177 \\
(0.000569)\end{array}$ \\
\hline \multicolumn{6}{|l|}{$\Delta \log$ number of school graduates } \\
\hline$g_{s t, t-1}$ & & $\begin{array}{c}0.0855^{* * *} \\
(0.0235)\end{array}$ & $\begin{array}{c}0.0561 * * \\
(0.0253)\end{array}$ & $\begin{array}{c}0.0517 * * \\
(0.0254)\end{array}$ & $\begin{array}{c}0.0498^{* *} \\
(0.0254)\end{array}$ \\
\hline$\Delta \overline{B C I}_{Q 2 t-1, t-2}$ & & & $\begin{array}{l}-0.000123 \\
(0.000477)\end{array}$ & $\begin{array}{l}-0.000285 \\
(0.000482)\end{array}$ & $\begin{array}{l}-0.000281 \\
(0.000482)\end{array}$ \\
\hline \multicolumn{6}{|l|}{$\Delta \log$ number of school graduates } \\
\hline$g_{s t-1, t-2}$ & & & $\begin{array}{c}0.158 * * * \\
(0.0220)\end{array}$ & $\begin{array}{c}0.149 * * * \\
(0.0222)\end{array}$ & $\begin{array}{l}0.129 * * \\
(0.0225)\end{array}$ \\
\hline Trend*East Germany & & & & & $\begin{array}{c}-0.0252 * * * \\
(0.00327)\end{array}$ \\
\hline Occupation-level trends & No & No & No & Yes & Yes \\
\hline Constant & $\begin{array}{c}-0.0288 * * * \\
(0.00164)\end{array}$ & $\begin{array}{c}-0.0271 * * * \\
(0.00168) \\
\end{array}$ & $\begin{array}{c}-0.0187 * * * \\
(0.00180) \\
\end{array}$ & $\begin{array}{c}-0.297 * * * \\
(0.0467) \\
\end{array}$ & $\begin{array}{c}-0.297 * * * \\
(0.0467) \\
\end{array}$ \\
\hline Observations & 33754 & 33754 & 30129 & 30129 & 30129 \\
\hline R-squared & 0.000 & 0.001 & 0.001 & 0.014 & 0.015 \\
\hline
\end{tabular}

Notes: Heteroskedasticity and autocorrelation-robust standard errors in parentheses. *** Significant at the $1 \%$ level; ** significant at the 5\%-level; * significant at the $10 \%$ level. Data sources: Vocational training statistics of the statistical offices of the federal and state governments, ifo Business Climate Index.

Table A6: First-differences regression (occupation-state-level, apprentices with low-level school degree)

\begin{tabular}{lccccc}
\hline Dependent variable (log): $\Delta a_{\text {ost }, t-1}$ & Model 1 & Model 2 & Model 3 & Model 4 & Model 5 \\
\hline$\Delta \overline{B C I}_{Q 2 t, t-1}$ & $0.00149^{* *}$ & $0.00126^{* *}$ & $0.00142^{* *}$ & $0.00143^{* *}$ & $0.00144^{* *}$ \\
& $(0.000621)$ & $(0.000627)$ & $(0.000656)$ & $(0.000663)$ & $(0.000663)$ \\
$\Delta$ log number of school graduates & & & & & \\
$g_{s t, t-1}$ & & $0.109^{* * *}$ & $0.0657^{*}$ & 0.0455 & 0.0406 \\
& & $(0.0372)$ & $(0.0398)$ & $(0.0400)$ & $(0.0403)$ \\
$\Delta \overline{B C I}_{Q 2 t-1, t-2}$ & & & 0.000535 & 0.000449 & 0.000447 \\
& & & $(0.000580)$ & $(0.000585)$ & $(0.000585)$ \\
$\Delta \log$ number of school graduates & & & 0.0342 & 0.0142 & 0.0160 \\
$g_{s t-1, t-2}$ & & & $(0.0383)$ & $(0.0386)$ & $(0.0386)$ \\
& & & & & $0.0178^{* *}$ \\
Trend*East Germany & No & No & No & Yes & Yes \\
& $-0.0348^{* * *}$ & $-0.0292^{* * *}$ & $-0.0297 * * *$ & 0.554 & 0.554 \\
Occupation-level trends & $(0.00196)$ & $(0.00264)$ & $(0.00315)$ & $(0.388)$ & $(0.388)$ \\
Constant & 26851 & 26851 & 24046 & 24046 & 24046 \\
& 0.000 & 0.001 & 0.000 & 0.013 & 0.014 \\
\hline Observations & & & & \\
R-squared
\end{tabular}

Notes: Heteroskedasticity and autocorrelation-robust standard errors in parentheses. *** Significant at the 1\%level; ** significant at the $5 \%$-level; * significant at the $10 \%$ level. Data sources: Vocational training statistics of the statistical offices of the federal and state governments, ifo Business Climate Index. 
Figure A1: Beveridge curves for South German states (2007-2019)

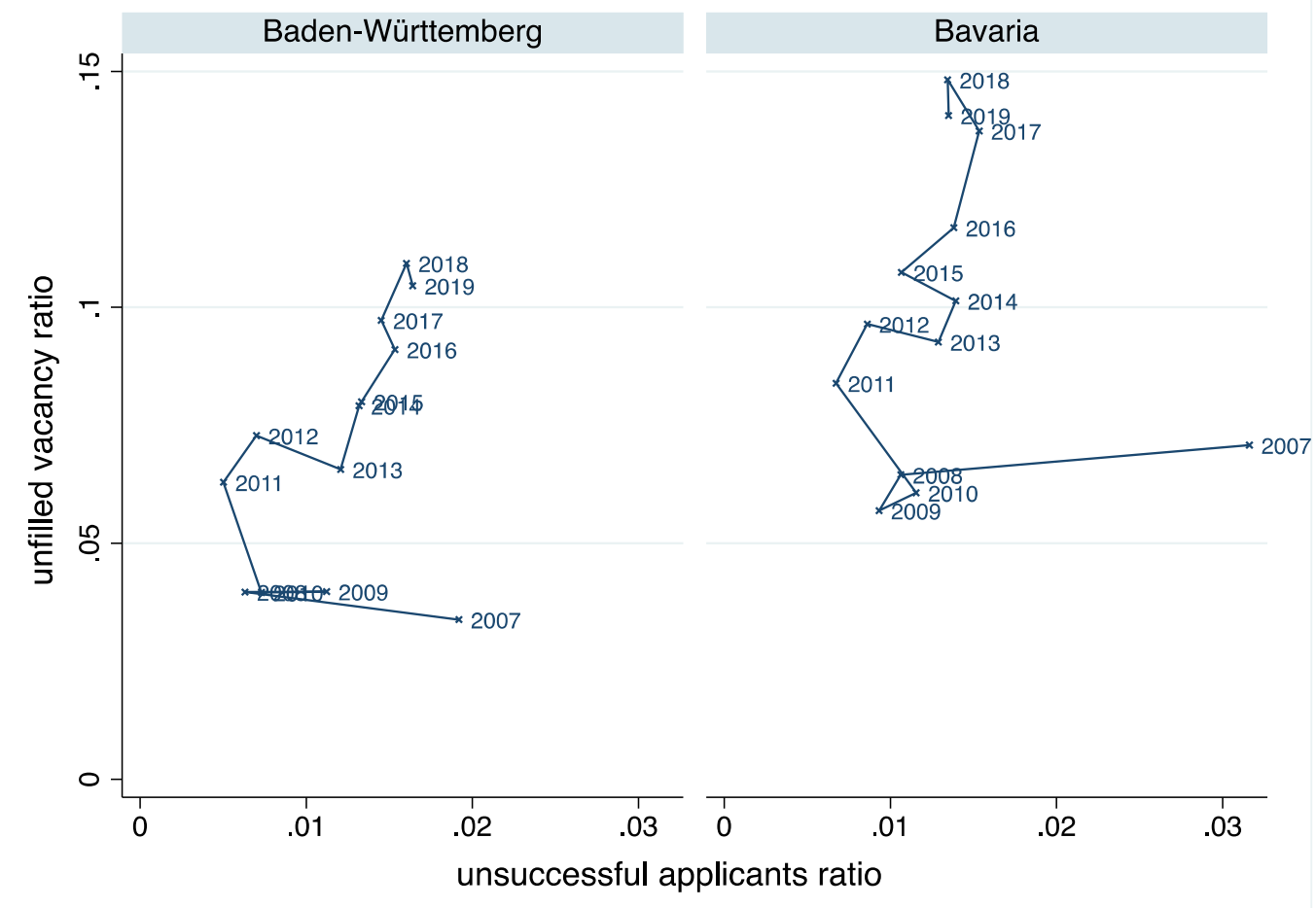

Data sources: Vocational training statistics of the statistical offices of the federal and state governments.

Figure A2: Beveridge curves for West German states (2007-2019)

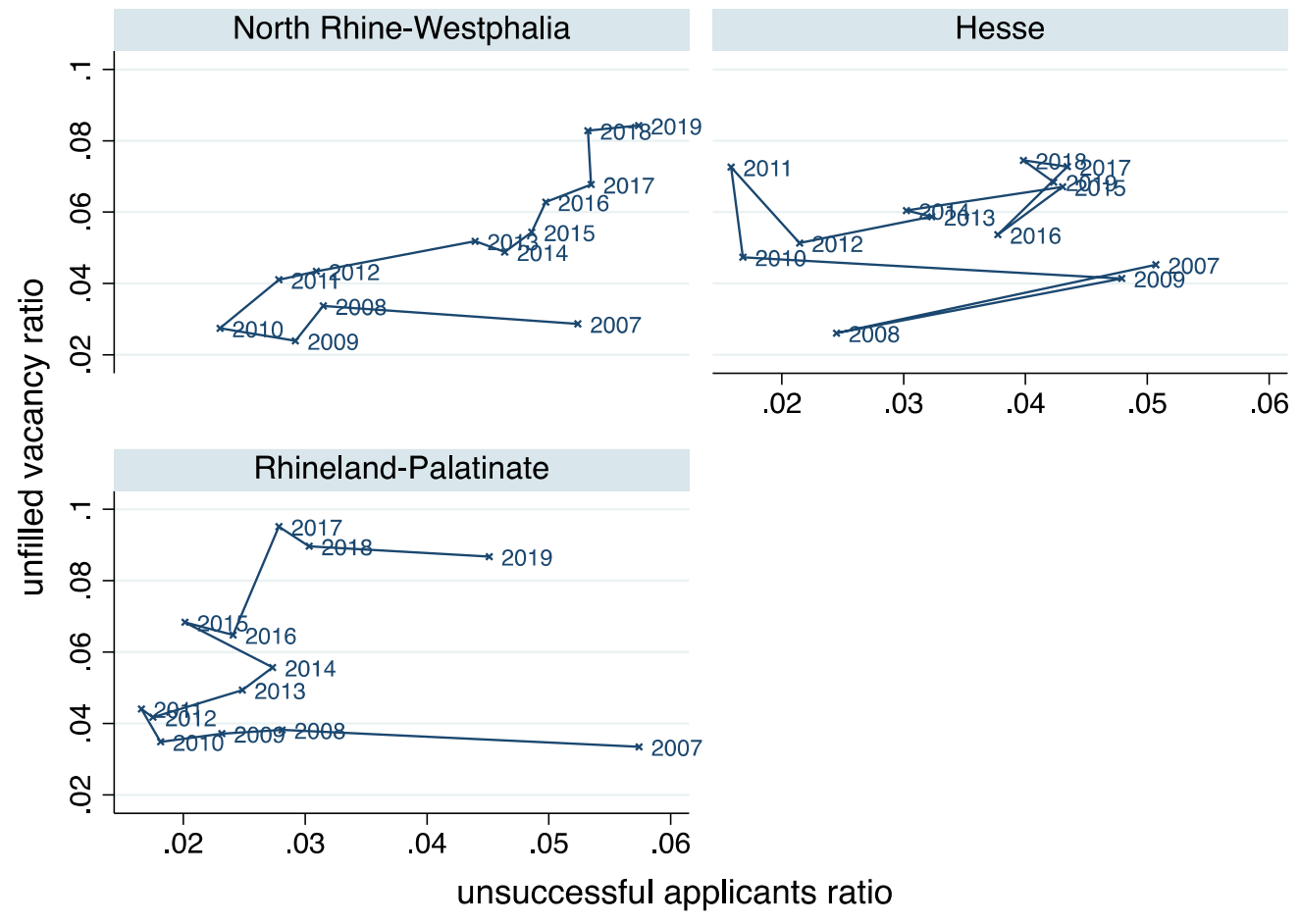

Data sources: Vocational training statistics of the statistical offices of the federal and state governments. 
Figure A3: Beveridge curves for North-Western German states (2007-2019)

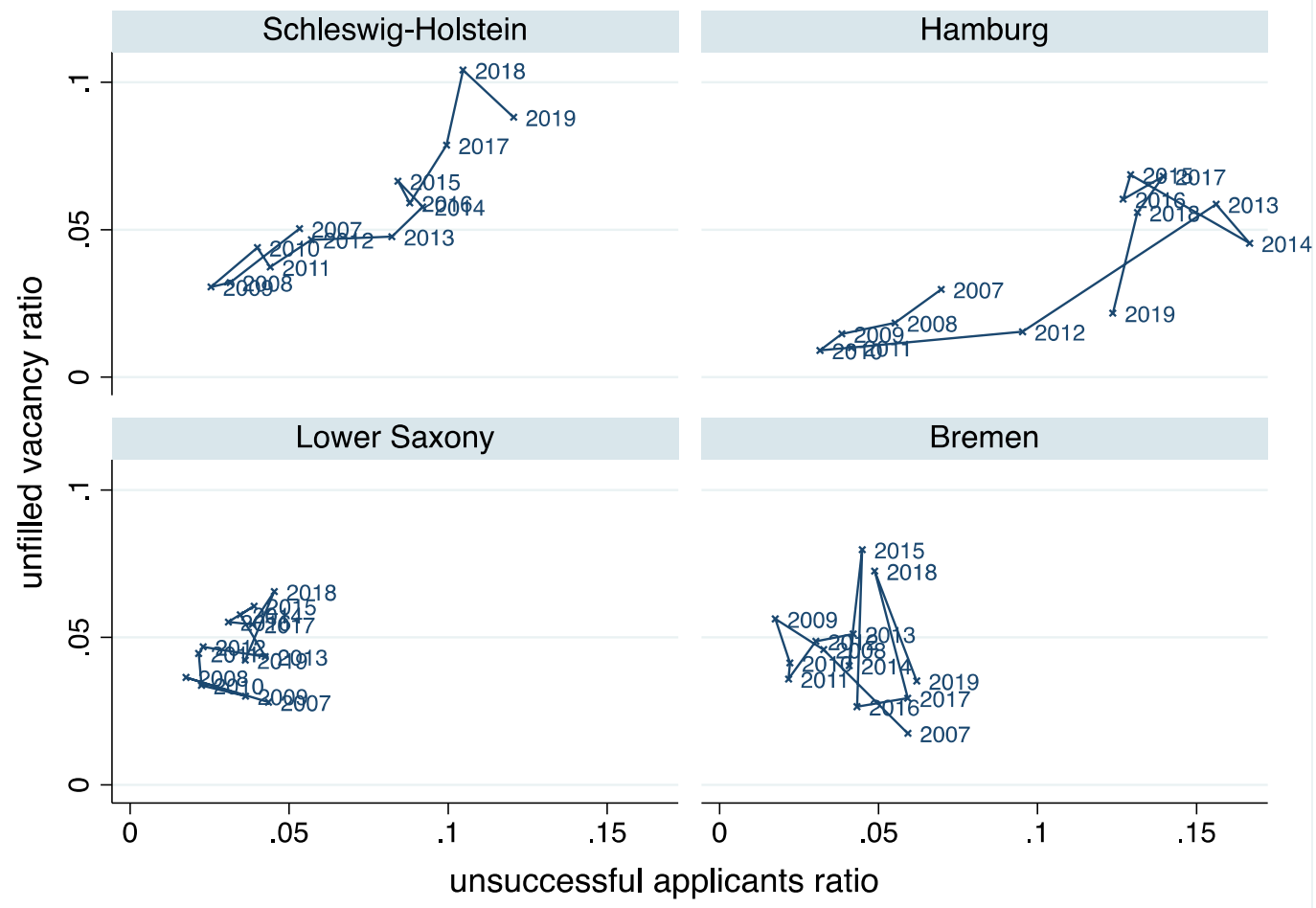

Data sources: Vocational training statistics of the statistical offices of the federal and state governments.

Figure A4: Beveridge curves for East German states (2007-2019)

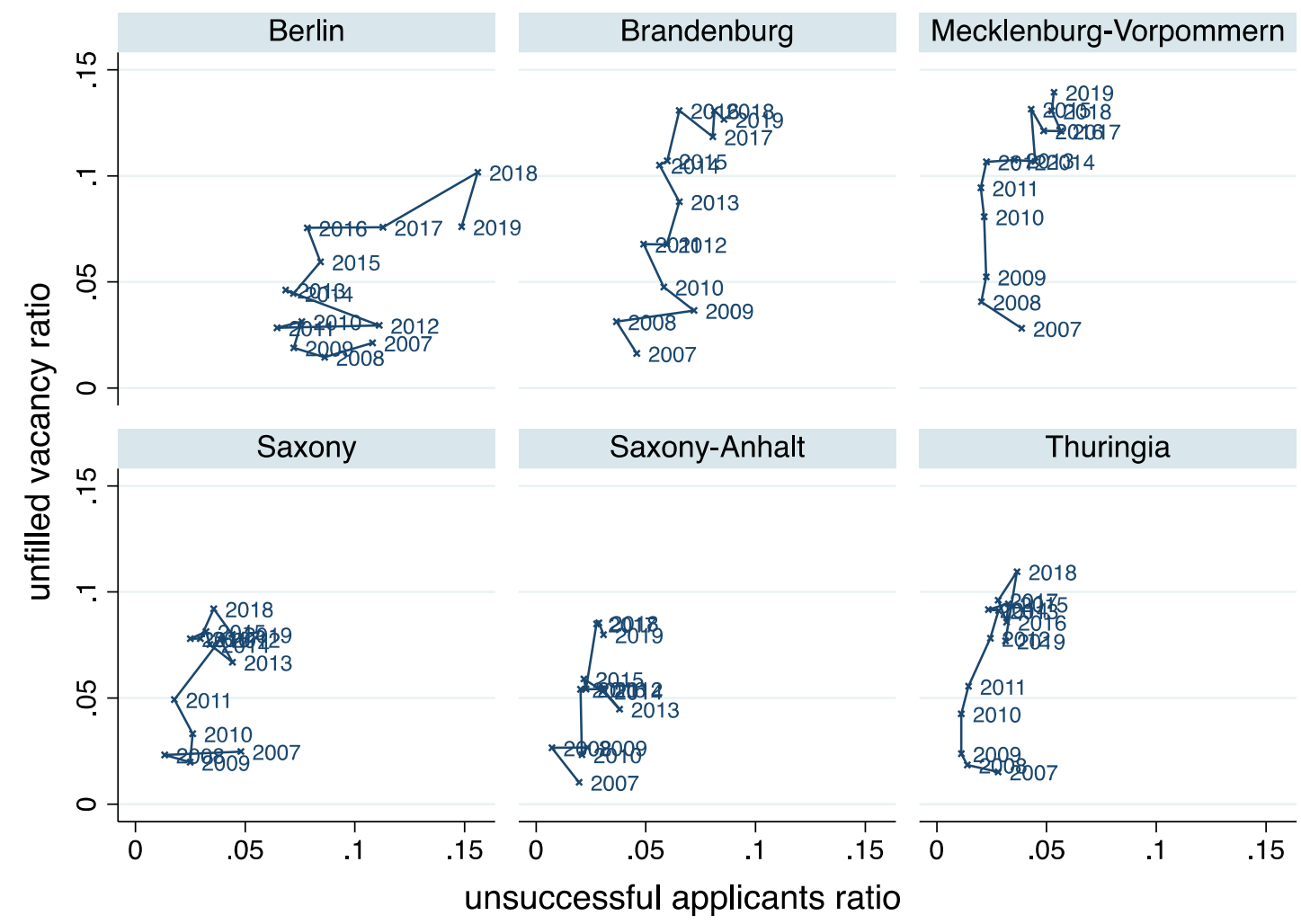

Data sources: Vocational training statistics of the statistical offices of the federal and state governments. 
Figure A5: Share of unfilled vacancies in craft (HWK) and industry \& trade (IHK) for South German states, 2015-2019

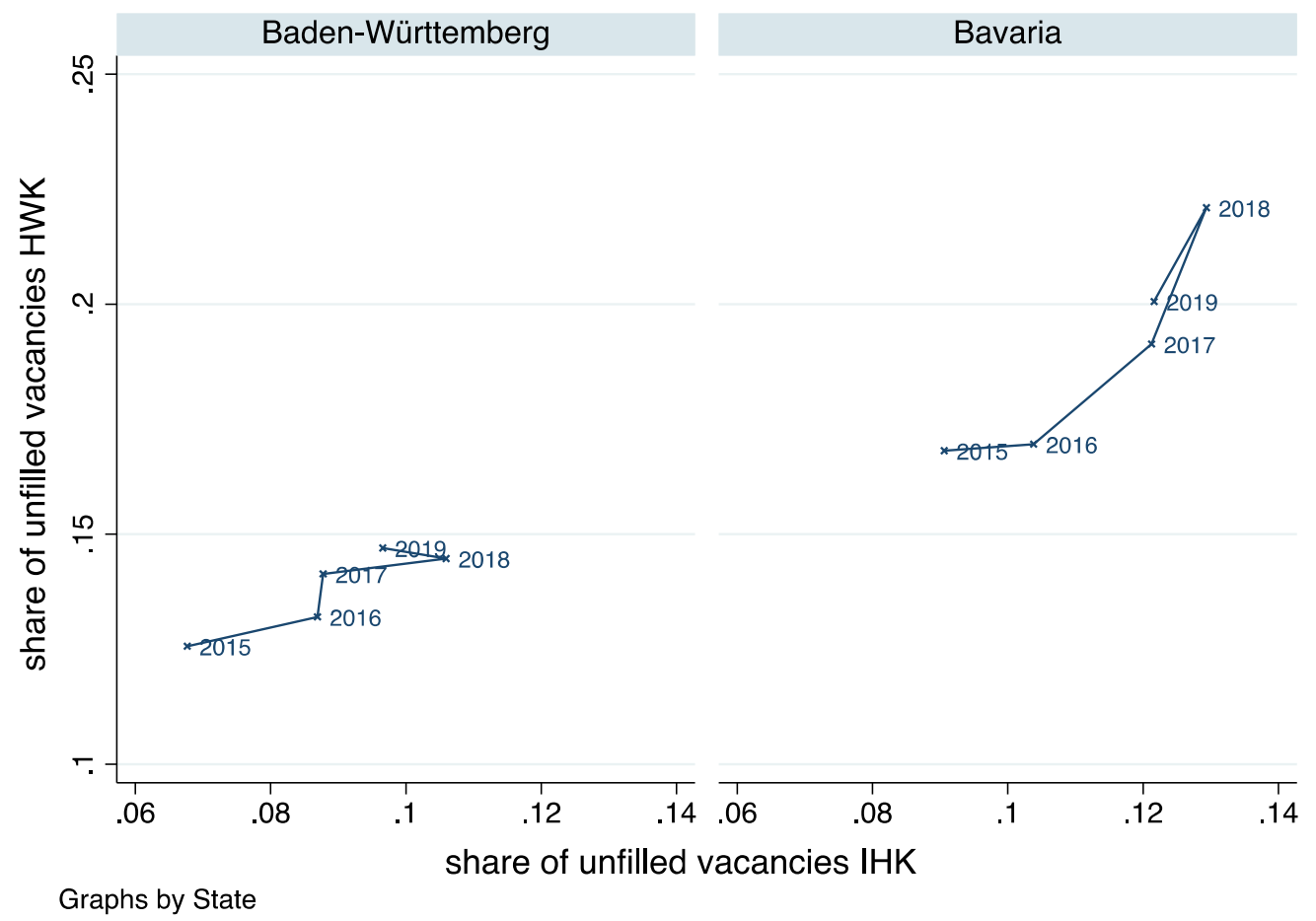

Data sources: Vocational training statistics of the statistical offices of the federal and state governments.

Figure A6: Share of unfilled vacancies in craft (HWK) and industry \& trade (IHK) for West German states, 2015-2019

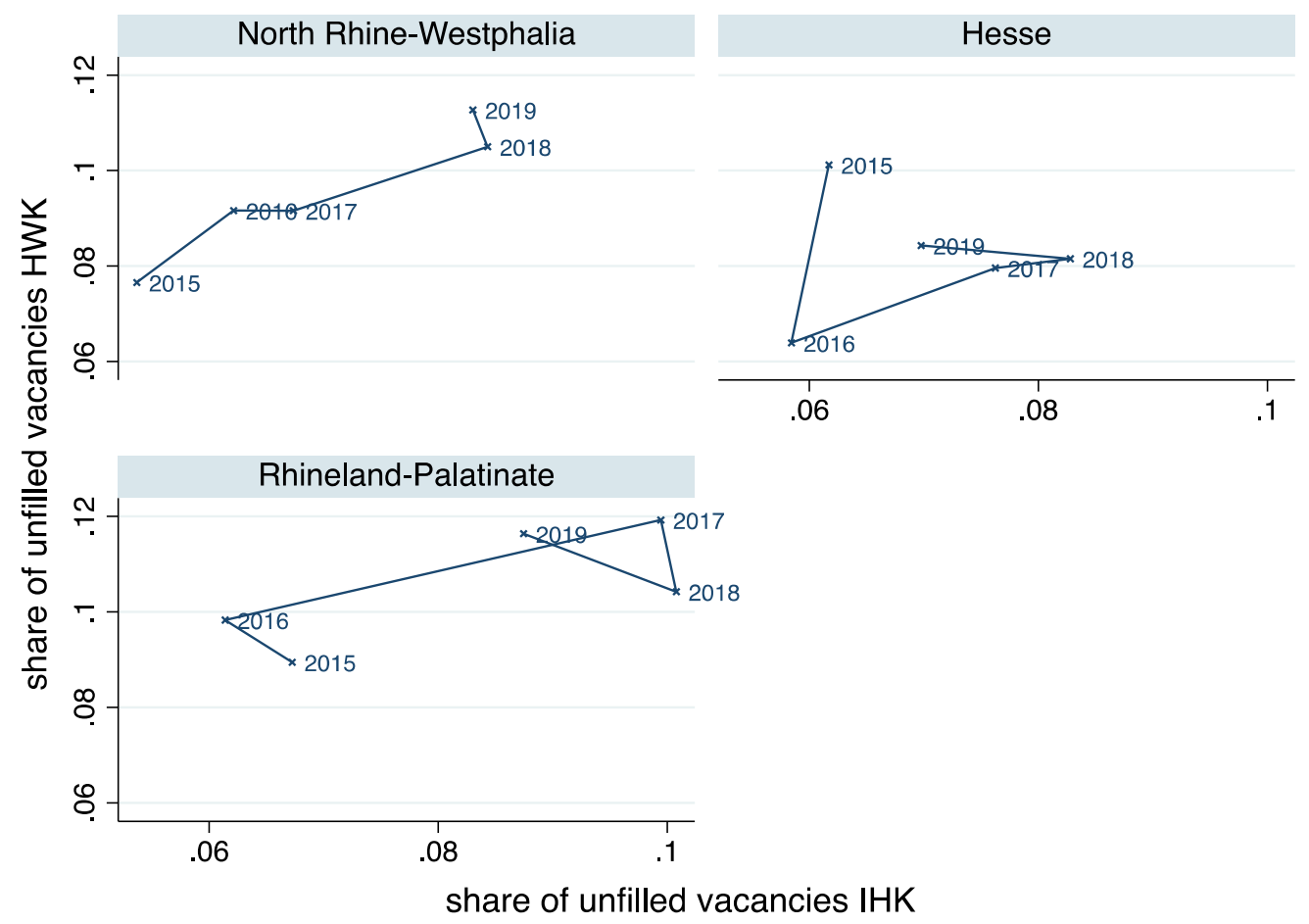

Data sources: Vocational training statistics of the statistical offices of the federal and state governments. 
Figure A7: Share of unfilled vacancies in craft (HWK) and industry \& trade (IHK) for North-Western German states, 2015-2019

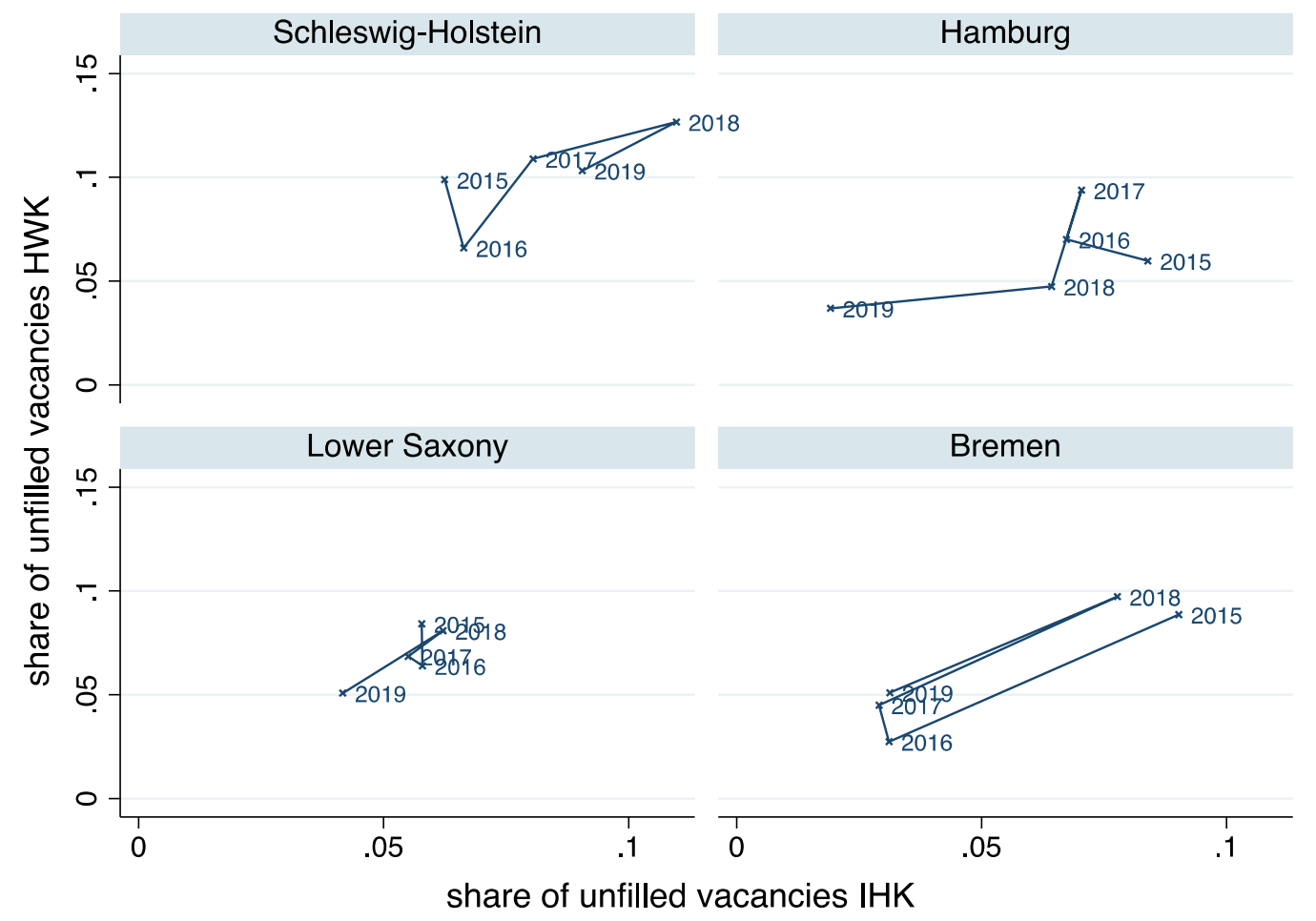

Data sources: Vocational training statistics of the statistical offices of the federal and state governments.

Figure A8: Share of unfilled vacancies in craft (HWK) and industry \& trade (IHK) for East German states, 2015-2019

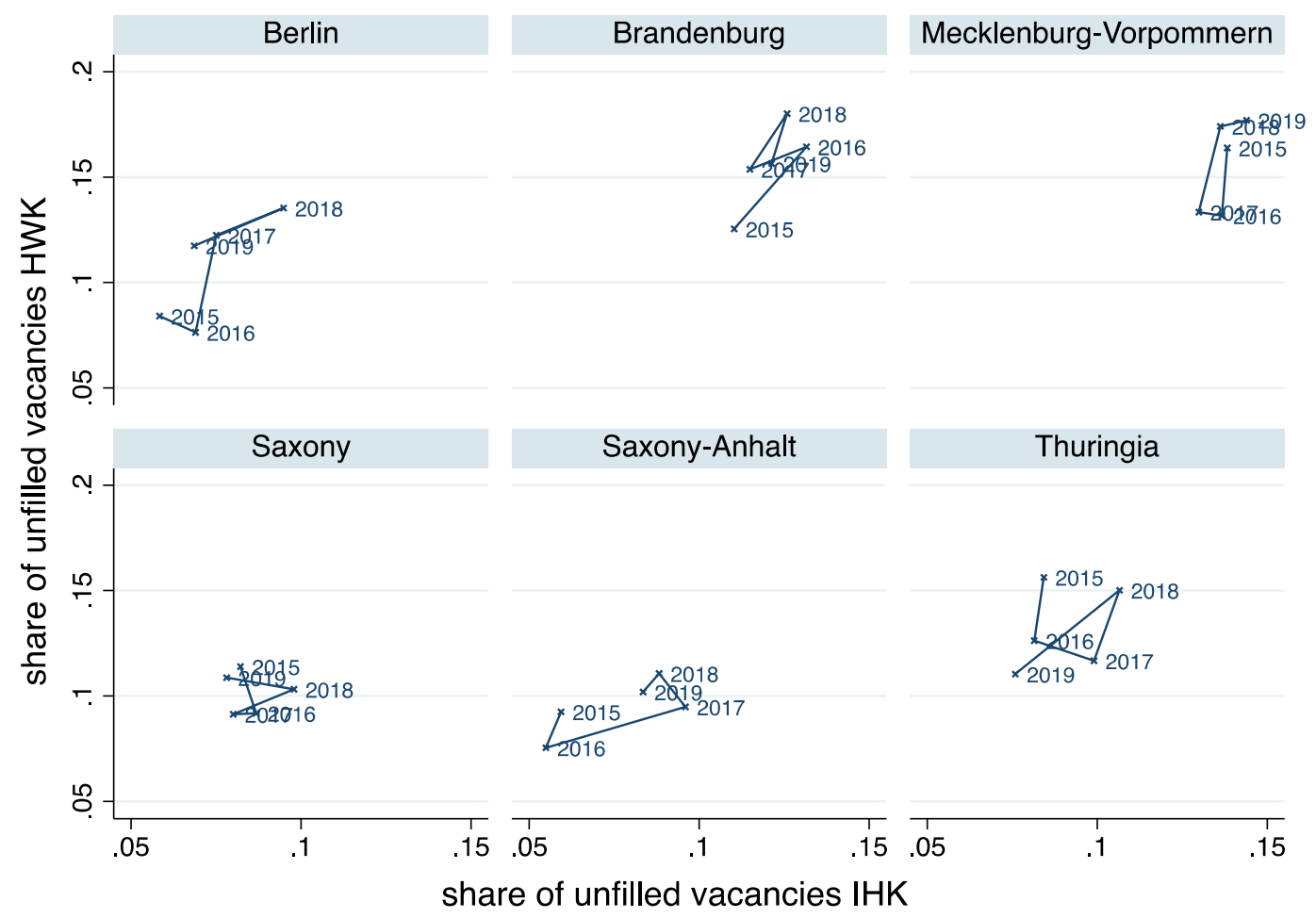

Data sources: Vocational training statistics of the statistical offices of the federal and state governments. 